\title{
CELL FORMATION CONSIDERING FUZZY DEMAND \\ AND MACHINE CAPACITY
}

BY

DAVID GREGORY SZWARC

\author{
A Thesis \\ Submitted to the Faculty of Graduate Studies \\ in Partial Fulfillment of the Requirements \\ for the Degree of \\ MASTER OF SCIENCE \\ Department of Mechanical and Industrial Engineering \\ University of Manitoba \\ Winnipeg, Manitoba
}

(c) March, 1996: David Gregory Szwarc 
Bibliothèque nationale

du Canada

Direction des acquisitions et des services bibliographiques

395, rue Wellington

Ottawa (Ontario)

K1A ON4
Your file Votre référence

Our file Notre référence
The author has granted an irrevocable non-exclusive licence allowing the National Library of Canada to reproduce, loan, distribute or sell copies of his/her thesis by any means and in any form or format, making this thesis available to interested persons.
L'auteur a accordé une licence irrévocable et non exclusive permettant à la Bibliothèque nationale du Canada de reproduire, prêter, distribuer ou vendre des copies de sa thèse de quelque manière et sous quelque forme que ce soit pour mettre des exemplaires de cette thèse à la disposition des personnes intéressées.

L'auteur conserve la propriété du droit d'auteur qui protège sa thèse. Ni la thèse ni des extraits substantiels de celle-ci ne doivent être imprimés ou autrement reproduits sans son autorisation. 
Name

Dissertation Abstracts International and Masters Abstracts International are arranged by broad, general subject categories. Please select the one subject which most nearly describes the content of your dissertation or thesis. Enter the corresponding four-digit code in the spaces provided.

IXDUKTRHL ENGINEERIN : CELL FORMATION SUBJECT TERM
$015 \sqrt{416}$ UMI SUBJECT CODE

\section{Subject Categories}

\section{THE HUMANITIES AND SOCIAL SCIENCES}

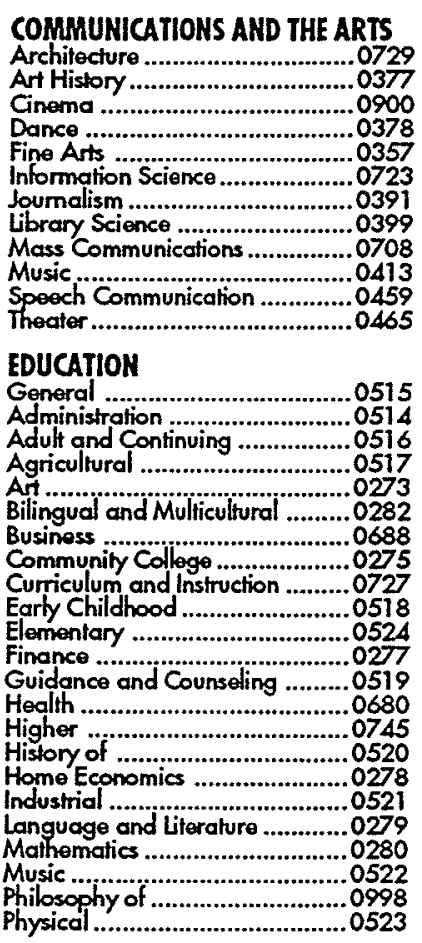

PHILOSOPHY, RELIGION AND THEOLOCY

Philosophy................................0422

Religion

General ................0378

Biblical Studies .........................0321

Clergy ................................0379

History of .............................0320

Theotogy .................................... 0469

\section{SOCIAL SCIENCES}

American Sludies ......................0323

Anthropology

Archaeology ........................0324

Cultural ..............................0326

Physical ..................

General .............................0310

Accounting ........................0272

Banking ..............................0770

Management .........................0454

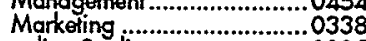

Canadian Studies .................... 0338

Economics

Goneral ..............................0501

Agricultural...........................0503

Commerce-Business .............. 0505

Finance ............................0508

History ................................0509

Labor .......................................... 0510

Theory ...................................051

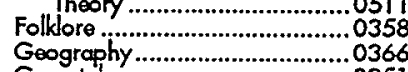

Geography................................0366

History

$$
\text { General }
$$

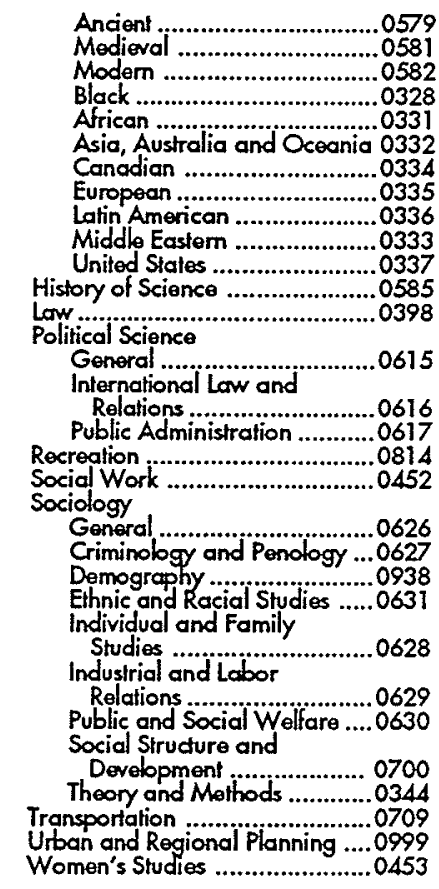

THE SCIENCES AND ENGINEERING BIOLOGICAL SCIENCES

Agriculture

General ..............................0473

Agronomy .............................0285

Animal Culture and

Nutrition ..........................0475

Animal Pathology.................0476

Food Science and

Technobgy ..................0359

Forestry and Wildifie .............0478

Plant Culture .......................0479

Plant Physiology .....................0817

Range Managoment .............0777

Wood Technology ...................0746

jology

General ...............................0306

Anabomy ...............................0287

Botany …………........................

Coll ................................. 0379

Ecology ...................................0329

Entomology …....................... 0353

Genetics ...................................0369

imnology..................................0793

Mierobiology ..........................0410

Molecular ………………….....0307

Neuroscience .......................0317

Ocoanagraphy ....................0416

Rodiation........................0821

Veterinary Science ..................0778

Zoology ................................0472

Biophysics

General ................................0786

Modical ..................................0760

EARTH SCIENCES

Biogeochemistry
Geochemistry...

.0425

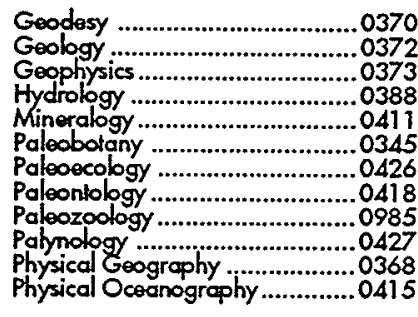

\section{HEALTH AND ENVIRONMENTAL}

\section{SCIENCES}

Emvironmental Sciences .............0768

Health Sciences

General ..............................0566

Audiology ..............................0300

Chemotherapy .................... 0992

Dontistry .............................0567

Education .........................0350

Human Development ...........0758

Immunology ……….............0982

Modicine and Surgary ...........0564

Mental Hodith ……........0347

Nursing .................................0569

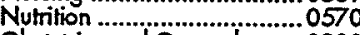

Obstetrics and Gynecotogy ..0380

Occupational Health and

Therapy .............................0354

Ophithalmobgy ......................0381

Pahthology ................................057

Pharmacology .......................0419

Pharmacy ..............................0572

Physical therapy ...................0382

Public Hoalth ........................0573

Recreation ............................0575
Spoech Pathology .................0460 Toxicology ................................0383 Home Economics .........................0386

\section{PHYSICAL SCENCES}

\section{Pure Sciences}

Chemistry

Analytical ...............................0486

Biochemistry ........................0487

Inorganic ...........................0488

Nuclaar …..........................0738

Organic............................0491

Physical ................................0494

Physical ................................0494

Rodiation .......................................0754

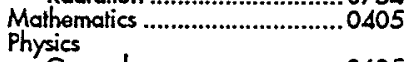

General ...............................0605

Acoustics..........

Astrophysies $\quad 0606$

Afmospheric Science...............0608

Atomic.... Science............0608

Electronics and Electricily ......0607

Elementary Particles and

High Energy.

Fluid and Plasma ....................0798

Molocular

Nuclear ..........................................

Optics .................................0752

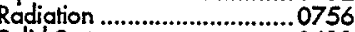

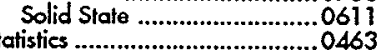

Applied Sciences

Applied Mechanics .0346

Compuler Science ..........................0984
General ............................0485

Agricultural ...........................0749
Engineoring

General ...0537

Aerospace ...........................0538

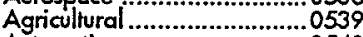

Automotive ............................. 0540

Biomedical ................................ 0541

Chemical ................................0542

Civil .............................0543

Heat and Thermodynamics ..0348

Hydraulic .............................0545

Industrial ...............................0546

Marine ...............................0547

Malerials Science ................0794

Mechanical ............................0548

Metallurgy .................................0743

Mining ..................................0551

Packaging ..............................0549

Perroleum..........................0765

Sanitary and Municipal ......... 0554

System Science ......................0790

Geotechnology ...............................0428

Operations Research .................... 0796

Plastics Technology .......................0795
Textile Technology ....................0994

\section{PSYCHOLOGY}

General ....................................0621

Behovioral ................................... 0384

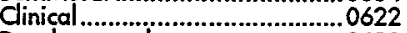

Developmental .............................0620

Experimental ............................0623

industrial ...................................0624

Physioti..........................068

Psychobiology ................................. 0349

Social........................................ 0451
Psychometrics ..................................0632 
THE UNIVERSITY OF MANITOBA

FACULTY OF GRADUATE STUDIES

$\star \star \star * *$

COPYRIGHT PERMISSION

CELI FORMATION CONSIDERING FUZZY DEMAND

AND MACHINE CAPACITY

BY

DAVID GREGORY SZWARC

A Thesis/Practicum submitted to the Faculty of Graduate Studies of The University of Manitoba in partial fulfillment of the requirements for the degree

of

MASTER OF SCIENCE

(c) 1996

Permission has been granted to the Library of The University of Manitoba to lend or sell copies of this thesis/practicum, to the National Library of Canada to microfilm this thesis and to lend or sell copies of the film, and to University Microfilms Inc. to publish an abstract of this thesis/practicum.

This reproduction or copy of this thesis has been made available by authority of the copyright owner solely for the purpose of private study and research, and may only be reproduced and copied as permitted by copyright laws or with express written authorization from the copyright owner. 


\section{ABSTRACT}

The concept of Cellular Manufacturing requires that machines and parts be grouped together to form cells. Many researchers have addressed this cell formation problem under crisp or certain input data. However, if the input data is not exact or is imprecise (fuzzy), how is the decision made to form cells and assign parts determined? In this thesis, crisp and fuzzy mathematical models are developed to optimally determine machine grouping and parts assignment under fuzzy demand and machine capacity. The objective of these models are to minimize the processing and the material handling costs. Comparisons between the crisp and fuzzy results are made to show how outcomes differ when the uncertainty is introduced. The example problems are solved using the Hyperlindo software package to illustrate the ability of the model to react under different input parameters. To reduce the computation time, non-linear representations of the above crisp and fuzzy models are developed. These non-linear formulations allow each model to be elegantly decomposed into two sub-models. An iterative solution procedure is proposed which utilizes these sub-models to substantially reduce computation time. Example problems are solved using both the crisp and the fuzzy optimal models and the iterative procedure. The solutions and computational experience between the two approaches are compared. 


\section{ACKNOWLEDGEMENTS}

I would like to express my deepest appreciation and gratitude to my thesis supervisor, Dr.

D. Rajamani for his guidance, assistance and never ending support. My thanks also go out to the examination committee members Dr. C. R. Bector and Dr. D. Strong for their time, suggestions and constructive remarks.

I would like to thank my friends and colleagues for their loyalty, support and encouragement during the stressful and the trying times.

Finally, I wish to dedicate this thesis to my parents and family whose constant support and unflinching belief in my abilities have been a source of strength and inspiration throughout my university career. 


\section{TABLE OF CONTENTS}

Page

$\begin{array}{lr}\text { ABSTRACT } & \text { i } \\ \text { ACKNOWLEDGEMENTS } & \text { ii } \\ \text { LIST OF FIGURES } & \text { vi } \\ \text { LIST OT TABLES } & \text { vii } \\ \text { NOMENCLATURE } & \text { ix }\end{array}$

1.0 INTRODUCTION

1.1 Cellular Manufacturing 2

1.2 Cell Formation 3

1.3 Material Handling 4

1.4 Alternative Process Plans 6

$\begin{array}{ll}1.5 & \text { Organization of the Thesis } \\ \end{array}$

$\begin{array}{lll}2.0 & \text { LITERATURE SURVEY } & 8\end{array}$

2.1 Cell Formation $\quad 8$

2.2 Material Handling 9

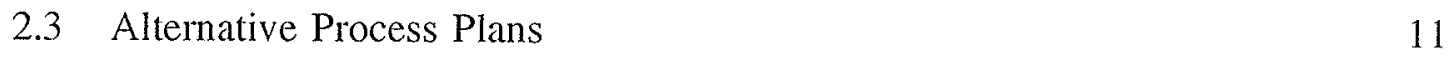

$\begin{array}{lll}2.4 & \text { Fuzzy Considerations } & 12\end{array}$

$\begin{array}{ll}\text { 2.5 Motivation For The Proposed Research } & 14\end{array}$ 


\subsection{MATHEMATICAL MODELS FOR CELL FORMATION WITH} FUZZY DEMAND AND MACHINE CAPACITY CONSIDERATIONS 16

$\begin{array}{lll}3.1 & \text { Assumptions } & 17\end{array}$

$\begin{array}{lll}3.2 & \text { Terminology } & 17\end{array}$

$\begin{array}{lll}3.3 & \text { Crisp Mathematical Model } & 18\end{array}$

3.4 Membership Function Derivation 20

3.4.1 Membership Functions 21

3.5 Fuzzy Mathematical Model 24

3.6 Illustrative Examples And Discussion 25

3.6.1 Example 3.1 26

$\begin{array}{lll}\text { 3.6.2 Example } 3.2 & 27\end{array}$

$\begin{array}{lll}\text { 3.6.3 Example } 3.3 & 28\end{array}$

$\begin{array}{lll}\text { 3.6.4 Example 3.4 } & 29\end{array}$

$\begin{array}{lll}3.7 & \text { Summary } & 30\end{array}$

4.0 NON-LINEAR CRISP AND FUZZY MATHEMATICAL MODELS 42

4.1 Crisp Non-Linear Mathematical Model 43

4.2 Fuzzy Non-Linear Mathematical Model 44

4.3 Part Allocation Mathematical Models 46

4.3.1 Crisp Part Allocation Mathematical Model 46 
4.3.2 Fuzzy Part Allocation Mathematical Model 47

4.3.3 Crisp and Fuzzy Machine Location Mathematical Models 47

4.4 Iterative Solution Strategy 49

4.5 Illustrative Examples $\quad 50$

4.5.1 Example 4.1 50

4.5.2 Example 4.2 51

4.6 Computational Experience $\quad 53$

4.7 Summary $\quad 54$

5.0 CONCLUSHONS

5.1 Contributions of the Research 63

5.2 Scope for Future Research 64

$\begin{array}{ll}\text { REFERENCES } & 65\end{array}$ 


\section{LIST OF FIGURES}

Page

1.1: Machine\Part Matrix 4

3.1: Membership Function Representations 23

3.2: Initial Layout 26

3.3: Membership Function Value vs Tolerance 29

3.4: Membership Function Value vs Tolerance 29 


\section{LIST OF TABLES}

Page

3.1: Cost of Moving One Part Between Locations

3.2: Part Demand

3.3: Cost/Time(min) per Part Operation for each Machine

3.4: Part AssignmentMachine Location for Example 3.1

3.5: Part AssignmentMachine Location for Example 3.2

3.6: Part AssignmentMachine Location for Example 3.3

3.7: Part AssignmentMachine Location for Example 3.4

3.8: Summary of Results

4.1: Initial Machine Layout (Example 4.1)

4.2: Parts Assignment - Step $1^{\prime}$ (Example 4.1)

4.3: Machine Layout - Step $2^{\prime}$ (Example 4.1)

4.4: Parts Assignment - Step $1^{2}$ (Example 4.1)

4.5: Initial Machine Layout (Example 4.2)

4.6: Parts Assignment - Step $1^{1}$ (Example 4.2)

4.7: Machine Layout - Step 2' (Example 4.2)

4.8: Parts Assignment - Step $1^{2}$ (Example 4.2)

4.9: Machine Layout - Step $2^{2}$ (Example 4.2)

4.10: Parts Assignment - Step $1^{3}$ (Example 4.2)

60

4.11: Cost/Time(min) per Part Operation for each Machine 
4.12: Summary of Results

4.13: Summary of Model Size 


\section{NOMENCLATURE}

\section{Indexing Sets}

$\mathrm{f}=0,1, \ldots, \mathrm{G}$ location

$\mathrm{g}=1,2, \ldots, \mathrm{G}$ location.

$\mathrm{h}=1,2, \ldots, \mathrm{G}+1$ location

$\mathrm{k}=1,2, \ldots, \mathrm{K}$ operation.

$\mathrm{m}=1,2, \ldots, \mathrm{M}$ machine.

$\mathrm{n}=1,2, \ldots, \mathrm{M}$ machine.

$\mathrm{p}=1,2, \ldots, \mathrm{P}$ part.

\section{$\underline{\text { Parameters }}$}

$\mathrm{C}_{\mathrm{pkm}}=$ cost of performing part $\mathrm{p}$ 's $\mathrm{k}^{\mathrm{th}}$ operation on machine $\mathrm{m}$.

$\mathrm{D}_{\mathrm{gl} \mathrm{h}}=$ cost of making one trip from location $\mathrm{g}$ to location $\mathrm{h}$.

$D_{p}=$ demand for part $p$.

$\lambda \leq \mu_{i}(Y)(i=0,1, \ldots, P+M)$.

$\mu_{i}(Y)=$ membership function for constraint $i(i=0,1, \ldots, P+M)$.

$\mathrm{p}_{\mathrm{i}}=$ tolerance on constraint $\mathrm{i}(\mathrm{i}=0,1, \ldots, \mathrm{P}+\mathrm{M})$.

$t_{\mathrm{pkm}}=$ processing time required to perform part $\mathrm{p}^{\prime} \mathrm{s} \mathrm{k}^{\mathrm{tl}}$ operation on machine $\mathrm{m}$.

$\mathrm{T}_{\mathrm{m}}=$ the maximum available machining time on machine $\mathrm{m}$. 


\section{$\underline{\text { Decision Variables }}$}

$\mathrm{X}_{\text {manl }}=1$ if machine $\mathrm{m}$ is in location $\mathrm{g}$ and machine $\mathrm{n}$ is in location $\mathrm{h}, 0$ otherwise.

$Y_{p k m g h l}=$ the amount of part type $p$ whose $k^{(t)}$ operation is performed on machine $m$ in location $\mathrm{g}$ and is transported to location $\mathrm{h}$.

$Y_{p, k-1, m i g}=$ the amount of part type $\mathrm{p}$ whose $(\mathrm{k}-1)^{\mathrm{th}}$ operation is performed on machine $\mathrm{m}$ in location $f$ and is transported to location $g$.

$Y_{p k n m}=$ the amount of part type $p$ whose operation $k^{t / l}$ is performed on machine $\mathrm{m}$ and is transported to machine $\mathrm{n}$.

$Y_{p, k-1, n m 1}=$ the amount of part type $p$ whose operation $k-l^{\text {th }}$ is performed on machine $n$ and is transported to machine $\mathrm{m}$.

$Y_{\mathrm{mg}}=1$ if machine $\mathrm{m}$ is in location $\mathrm{g}, 0$ otherwise.

$Y_{n h}=1$ if machine $n$ is in location $h, 0$ otherwise. 


\subsection{INTRODUCTION}

Traditionally, the available alternatives for a manufacturing facility layout has been confined to three extremes. The first of these layouts is the fixed layout. In this layout, the manufacturing equipment is brought to the product; and consequently, is usually reserved for a single, large scale, product, such as ship building and the construction industry. The second type of layout is the flow-shop. In this layout, the manufacturing equipment is organized along the flow path of the product such that the required operations may be performed in sequential order. This particular layout is usually reserved for assembly line operations, such as automobile manufacturing, where product variety is low and volumes are high. The third type of layout is the job-shop. In this layout, similar manufacturing equipment are grouped together such as, the saws in one area, the lathes in another and the drills in yet another area. This layout is usually used when there is a low volume, high product variety.

In the past, due mainly to the simplicity in their incorporation, these layouts were used almost exclusively. However, with increasing competition, both foreign and domestic, industry has adopted a quest of producing the highest possible quality product at the lowest possible cost. Unfortunately, the majority of the manufacturing industry lies somewhere between a flow-shop and job-shop environment. High product variety and low volumes in a flow-shop environment results in frequent and massive set-up costs and poor machine utilization. Low product variety and high volumes in a job-shop 
environment results in high work in process and needless material handling costs. This prompted a need for development of a hybrid manufacturing environment; namely Cellular Manufacturing (CM).

The rest of the Chapter explains the main areas that should be addressed in $\mathrm{CM}$ and is organized as follows. Section 1.1 describes the philosophy of CM. The cell formation process is illustrated in Section 1.2. Section 1.3 details the influence that material handling has on the cell formation process. The benefits of incorporating alternate part routings are described in Section 1.4. The organization of the thesis is detailed in Section 1.5 .

\subsection{Cellular Manufacturing}

CM exploits the benefits of flow-shop and job-shop environments while minimizing their drawbacks by finding a compromise between the two. The philosophy used in CM is to group parts which require similar processing operations and machines which are capable of performing these operations into one area or cell. By forming cells in this manner, each part can be assigned to a cell where it receives all or most of the necessary operations required for its completion; thus, reducing, among other things, material handling costs and work in process. The major concern with CM is that the initial implementation. However, increasing research and computer technology is aiding in 
successful incorporation of CM in industry. Within the last decade, the focus in research on $\mathrm{CM}$ has increased substantially.

\subsection{Cell Formation}

Cell formation consists of grouping machines into cells and parts into families. The objective of these groupings are to allocate part families to machine cells such that the processing of a part family outside the allocated cell is minimized. For illustrative purposes, consider the cell formation example depicted in Figure 1.1. This example shows six machines and six parts grouped into two cells. Cell 1 contains machine group 1 (machines 1,2 and 3) and part family 1 (parts 1,2 and 3) while cell 2 contains machine group 2 (machines 4, 5 and 6) and part family 2 (parts 4, 5 and 6). A numerical entry in the chart indicates that the part requires an operation to be performed by that machine. The numerical value indicates the sequence of operations. For example, the second operation performed on part 1 is done by machine 2 . A blank entry in the chart indicates that the part does not require any processing by that machine. Voids are defined as a blank entry which appears inside a cell. Exceptional elements occur when a part is processed in more than one cell as can be seen with the second operation of part 4. Part 4 must visit both cells before its processing can be completed. 


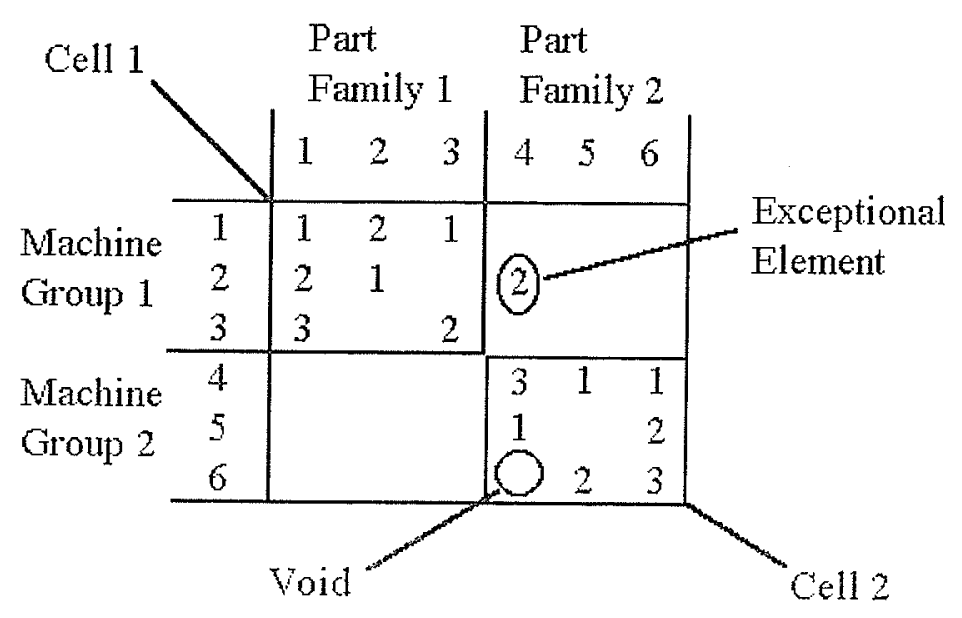

Figure 1.1: Machine\Part Matrix

\subsection{Material Handling}

Material handling occurs when a part is transported from one location to another to receive its next operation. In $\mathrm{CM}$, there are two types of material handling costs that can occur. The first is the intracell material handling costs. This occurs when a part moves between machines of the same cell. Referring to Figure 1.1, an intracell move occurs when part 1 moves from machine 1 to machine 2 to receive its second operation. Intercell material handling costs are the second type. These costs are incurred when a part moves between machines of different cells. Again referring to Figure 1.1, an intercell move occurs when part 4 moves from machine 5 to machine 2 to receive its 
second operation. Intercell moves are considered more disruptive and costly than intracell costs for various reasons, including longer travel distances and coordination problems in sequencing and scheduling. However, too large a cell size, although resulting in lower intercell costs, not only results in increased intracell costs (due to congestion and complex material handling systems) but also nullifies the other benefits of CM. Therefore, a tradeoff between the two handling costs have to be made during the cell formation process.

The largest contributors to material handling costs are part demand and sequence. High part demand will tend to place machines with high flow close together, preferably in the same cell; thereby, minimizing material handling. Conversely, low part demand will tend to place machines with low flow farther away. In todays fluctuating markets, demand may not be known exactly. Therefore, the inexactness or fuzziness of part demand should be addressed as well.

Sequence of operations also affects material handling costs. As evidenced in Figure 1.1, two intercell moves occur due to a single exceptional element (second operation of part 4). The first move occurs when the part moves from Cell 2 to Cell 1 and the second occurs when it moves back from Cell 1 to Cell 2. Therefore, part demand as well as sequence of operations can not be ignored. 


\subsection{Alternative Process Plans}

Alternative process plans occur whenever more than one machine is capable of performing the same operation on a part. Alternative process plans are beneficial in that they allow better groupability of parts with machines. For example, if both machines 2 and 6 could perform operation 2 on part 4, it would permit elimination of the exceptional element.

However, alternative process plans result in varying processing costs. For example, a new machine is usually quicker and more efficient than a similar older machine. Therefore, the machines with lower processing costs will tend to carry a larger share of production quantities. To ensure that the available operating capacity of a machine is not exceeded, the processing time of each part must be included in the cell formation as well. With the uncertainty of machine failures and varying operator skill levels the exact amount of available processing time can not be known. Addressing the fuzziness of machine capacity will provide a more realistic outcome.

\subsection{Organization of the Thesis}

This thesis is organized as follows. In Chapter 2, a literature review is presented. Crisp and fuzzy linear mathematical models which determine part allocation and machine layout 
are presented in Chapter 3. In Chapter 4, non-linear representations of the linear models are presented along with a corresponding iterative solution procedure. Several examples are solved which show the benefits of the solution procedure. Conclusions are provided in Chapter 5. 


\subsection{LITERATURE SURVEY}

$\mathrm{CM}$ has received a great deal of interest from a number of researchers, especially within the last decade. In this chapter, a comprehensive literature review is presented. In Section 2.1, a review of basic cell formation techniques is provided. Material handling effects on cell formation is reviewed in Section 2.2. Section 2.3 contains a review of the benefits achieved from the incorporation of alternative process plans on cell formation. Fuzzy considerations on cell formation are reviewed in Section 2.4. Motivation and objectives of the proposed research are provided in Sections 2.5 and 2.6, respectively.

\subsection{Cell Formation}

A number of authors have addressed the cell formation problem. Extensive reviews of the various approaches that have been applied to the cell formation problem may be found in Heragu (1994), Shafer and Meredith (1990) and Wemmerlov and Hyer (1986). Early efforts in the cell formation based the grouping of parts and machines around a similarity or compatibility indices. The pioneer of this technique was Kusiak (1987). Kusiak utilized the similarity between parts which was based on whether they visited the same machine. This similarity was then maximized using his p-median formulation. Srinivasan et al. (1989) utilized the similarity coefficient in an assignment model. Gunasingh and Lashkari (1989) maximized a compatibility index based on tooling requirements. A two 
stage formulation was provided by Choobineh (1988). In stage 1, part families were formed using a revised similarity coefficient. The formed part families were then used as input into Stage 2; the machine cell formation model. Gupta and Seifoddini (1990) used a revised similarity coefficient based on production parameters as input to their grouping algorithm.

\subsection{Material Handling}

As outlined in Chapter 1, material handling is a non-value adding operation that is comprised of two different costs; namely, intracell and intercell costs. Material handling has a great effect on the efficiency of a cells operation. Consequently, it has become the objective of many researchers to minimize these costs when forming cells. Logendran (1990) formed cells based on minimizing the number of intracell and intercell moves each part had to make based on a 0-1 matrix. Song and Hitomi (1992) maximized the number of parts produced in a cell so as to minimize the number of intercell moves. However, these two approaches neglected to incorporate part demand, sequence of operations and part splitting into their models.

Ahmed et al. (1991) offered a heuristic procedure which minimized material handling costs with demand considerations. Logendran (1991) showed that the sequence of operations is crucial in minimizing the total number of intercell moves. To minimize the 
number of intercell moves Murthy and Srinivasan (1995) create a remainder cell to house the exceptional elements. Grznar et al. (1994) proposed a nonlinear model which minimized a weighted intercell cost under capacity constraints. Del Valle et al. (1994) used a two objective heuristic. The first objective is to minimize the number of intercell moves while the second objective maximizes the utilization rate. Adil (1994) proposed a two stage, non-linear, integer programming model. Stage 1 groups machines by minimizing material handling costs based on demand and sequence of operations. In Stage 2, consideration of allocating operations to alternate and $\backslash$ r copies of machines were used to improve the solution obtained from Stage 1. Irani et al. (1993) minimizes intercell flow distances with flow direction considerations. Kasilingam and Sankaran (1991) formed cells based on processing, space utilization, amortization and intercell handling costs.

As identified in Chapter 1 , the sequence of operations has a significant effect on the number of intercell moves, depending on if it is the first, intermediate or final operation. Sequence dependence has been addressed by Rajamani et al. (1992) where the emphasis is on set up costs versus additional machine investment. Dahel (1995) uses part sequence along with machine capacity constraints to minimize intercell moves. 


\subsection{Alternative Process Plans}

The flexibility of alternative process plans offer immense flexibility in the cell formation process. As discussed in Chapter 1, the ability to perform the same operation on different machines aids in achieving mutually exclusive cells. Until recently, the exploitation of performing certain operations on more than one machine has received little attention.

A capacity oriented heuristic was proposed by Kang and Wemmerlov (1993). The heuristic grouped machines into cells based on reallocating part operations to machines. Parts were grouped by using a new similarity coefficient which combined parts that have a similar sequence of operations. A quadratic integer programming formulation and its corresponding linear formulation, Adil (1994), groups parts and machines simultaneously by minimizing the number of voids within a cell (intracell) and the number of exceptional elements outside a cell (intercell) considering alternative process plans. Rajamani et al. (1990) analyzed the effects that alternative process plans have on cell formation given demand, time and cost constraints. The effects of lot splitting is addressed by Logendran and Ramakrishna (1995). Lot splitting occurs when a part is manufactured in more than one cell. Rajamani et al. (1992) provide a part selection model. The model selects and groups the machines and the parts, which will allow maximum production quantities under demand, time and budget constraints, into cells. Askin and Mitwasi (1992) generated a layout based on maximizing revenue minus processing costs, material handling and machine location costs. Sankaran and Kasilingam (1993) determined the 
cell size as well as the cell composition based on space requirements, machine depreciation, material handling and processing costs. Rajamani and Szwarc (1994) and Atmani et al. (1995) addressed the machine replacement problem based on issues such as minimizing replacement, relocation, refixturing, material handling and processing costs.

However, none of the above references used the exact placement of machines in conjunction with the quantity of part flow between each machine to form cells; thereby, overunderestimating material handling costs. In Gupta and Seifoddini (1990) it is reported that one-third of US companies undergo major dislocation of production facilities (a physical rearrangement of two-thirds or more of the facilities) every two years. Along with every new grouping of machines, a new part assignment must also be made. Therefore, it is imperative that machine grouping be considered simultaneously with part assignment.

\subsection{Fuzzy Considerations}

In forming cells, it is desirable to use data that is steady and predictable. Two important data requirements are the required demand and the available machine capacity. Over time, demand for products and product mixes change along with consumer needs. Changing demand leads to machine loading imbalances and uncertain forecasting. Similarly, as machines age, the available machining times decrease, causing additional 
uncertainties in production planning. Therefore, deciding on the layout and quantity of each part to produce on each machine is difficult under certain (crisp) demand and machine capacity but how does uncertainty (fuzziness) affect the outcome. To deal with fuzzy data, both Zadeh (1965) and Zimmerman (1991) have produced relevant fuzzy logic concepts that are applicable to this situation. Tanaka and Asai (1984) detailed how to incorporate fuzzy parameters into a linear programming model.

Several authors have utilized these techniques of handling the impreciseness of data as applied to the cell formation problem. The part family formation problem was addressed by Xu and Wang (1989). For each part feature a degree of membership is assigned. A similarity coefficient between parts can then be made. This results in the grouping of parts that have the highest similarity between them. Zhang and Wang (1992) develop a non-binary machine/part matrix representing the degree of membership of parts to machines. This matrix contains the input data for the fuzzy SLC and ROC. Chu and Hayya (1991) applied a fuzzy clustering algorithm to group parts/machines into families. They allow a part to belong to more than one group by assigning a degree of membership, a value between 0 and 1, to each group. The closer the degree of membership to 1 , the greater the belongingness of that part to that group. By maximizing the degree of membership, they are able to determine the cell formation. Chu and Tsai (1993) provided a fuzzy formulation of a cell formation problem whose objective is to minimize the number of exceptional elements. Narayanaswamy (1995) groups parts and part process plans under fuzzy part demand and machine capacity constraints. However, 
these fuzzy approaches failed to consider the processing and the material handling costs as a basis for their cell formation procedure.

\subsection{Motivation For The Proposed Research}

The following served as motivators for the proposed research:

- The existing literature assumes that all intracellintercell moves cost the same without regard of the exact origins and destinations in the cell. This results in overvunderestimating the cost especially in the case of conveyor systems or automated guided vehicles that have circular paths.

- There is a need to consider the trade-off between processing and material handling costs (as defined above).

- There is a lack of research incorporating fuzzy concepts in the areas of demand and machine capacity with an objective of minimizing processing and material handling costs.

- No research has simultaneously grouped parts and machines with all the considerations (as defined above). 


\subsection{Objectives Of The Proposed Research}

The objective of the proposed research is as follows:

- To develop a mathematical model that simultaneously groups machines into cells and determines the quantity of each part to produce on each machine. The desired objective is to minimize the total cost of production by trading-off the intracell and intercell material handling costs with the processing costs when part demand and machine capacity are both crisp and fuzzy. A true measure of material handling costs (cost of part transfer between machines exact locations) should be incorporated in the models. The models should also considering all alternative routings and sequences. 


\subsection{MATHEMATICAL MODELS FOR CELL FORMATION WITH FUZZY DEMAND AND MACHINE CAPACITY CONSIDERATIONS}

In this chapter, a crisp and a fuzzy mathematical model is presented. The objective of the models are to allocate the parts individual operations to a specific machine(s) while simultaneously placing each machine into individual locations to minimize overall material handling and processing costs. When input data is considered to be uncertain, the crisp model may not provide accurate results. Therefore, a fuzzy model is used. The fuzziness in the model presented in this chapter occurs with the uncertainty of part demand forecasts and machine operating reliability. A comparison can then be made between the crisp and fuzzy solutions to see what effect the uncertainty has on the part assignment and machine placement. The mathematical models developed in this chapter are of a mixed integer type. It is first solved using crisp input data and then later solved using fuzzy input data for demand and machine capacity.

This chapter is organized as follows. Section 3.1 includes the assumptions that apply to both the crisp and fuzzy mathematical models. Section 3.2 contains the formulation of the crisp mathematical model. In Section 3.3, the membership functions required for the formulation of the fuzzy model are presented. Section 3.4 contains the formulation of the fuzzy mathematical model. Examples are provided and a comparison is made between the results of the crisp and fuzzy mathematical models in Section 3.5. The chapter is then concluded in Section 3.6. 


\subsection{Assumptions}

The mathematical models presented in this thesis require that the following assumptions be made:

(1) The cost of moving a part between all locations is known for both intercell and intracell movement.

(2) The sequence of operations for each part is known.

(3) The material handling system is composed of Automated Guided Vehicles (AGVS) and can transport a maximum of one part per trip.

(4) The time to perform every operation for every part on every machine is known

(5) Part demand is known or approximately known.

(6) Machine capacities are known or approximately known.

(7) Number of cells and possible machine locations are known.

(8) Locations 0 and $\mathrm{G}+1$ are dummy locations or load $\backslash u n l o a d$ areas.

\subsection{Terminology}

There are several terms in both linear and fuzzy linear programming that may need some explanation.

(1) Membership function: A fuzzy set I contained in X is described by a membership 
function $\mu_{1}(x)$, which associates with each point in a given set of numbers $X$ a real number in the interval $[0,1]$ with the value $\mu_{1}(x)$ at $x$, where the value $\mu_{1}(x)$ represents the degree of membership of $x$ in I. As $\mu_{\mathrm{I}}(\mathrm{x})$ approaches 1 , the higher the degree of belongingness of $\mathrm{x}$ in $\mathrm{I}$.

(2) Continuous Variable: is a variable which can take any real value.

(3) Binary Variable: is a variable which can take either the value 0 or 1 only.

(4) Intracell movement: movement of parts within a cell.

(5) Intercell movement: movement of parts between cells.

\subsection{Crisp Mathematical Model}

In the crisp model all the data provided is assumed to be precise. The crisp mathematical model is now presented. The objective function for this model consists of two costs. The first term represents the material handling costs while the second term represents the processing costs.

$$
\text { MINIMIZE } \sum_{p} \sum_{k} \sum_{m} \sum_{g} \sum_{h}\left(D_{g h}+C_{p k m}\right) Y_{p k m g h}
$$

subject to:

$$
\sum_{m} \sum_{g} \sum_{h} Y_{p l i n g h} \geq D_{p} \quad \forall p
$$




$$
\begin{gathered}
\sum_{p} \sum_{k} \sum_{h} t_{p k n} Y_{p k m g h} \leq T_{m} Y_{m g} \quad \forall m, g \\
\sum_{m} \sum_{f} Y_{p, k-1, m f g}=\sum_{m} \sum_{h} Y_{p k m g h} \quad \forall p, k, g \\
\sum_{m} Y_{m g}=1 \quad \forall g \\
\sum_{g} Y_{m g}=1 \quad \forall m \\
Y_{p k m g h} \geq 0 \\
\quad \forall p, k, m, g, h \\
Y_{m g}=0,1 \\
\forall m, g
\end{gathered}
$$

The crisp mathematical model contains six sets of constraints. The demand constraints (3.2) are used to ensure that the demand for every part is met. To avoid counting each part more than once, the demand equation is summed over the first operation only. The machine capacity constraints (3.3) are used for two reasons. The first reason is to ensure that the available machining time on each machine is not exceeded. The second reason is to ensure that if a machine is not located in a location, there cannot be any production of parts on that machine in that location. The flow equilibrium constraints (3.4) ensure that if a part enters a location it must leave the location. They also ensure that every part receives all of their required operations (this equation assumes no loss due to scrap). 
Locations 0 and $\mathrm{G}+1$ may be considered dummy locations or loadunload areas. The machine assignment constraints (3.5) and (3.6) are required to ensure that only the machines that can be relocated are being considered for relocation. They are also used to ensure that there is exactly one machine is in each location and each location has exactly one machine in it. The non-negativity constraints (3.7) ensure that the variables are not assigned negative values. Constraints (3.8) are required to ensure that the variables are assigned binary values only.

If desired, the mathematical model can be modified to include relocation and replacement costs of machines. This is accomplished by adding the following term to the objective function:

$$
\sum_{m} \sum_{g} C_{m g} Y_{m g}
$$

The coefficient $C_{m g}$ represents the cost associated with placing machine $m$ in position $g$. It can include costs such as purchase price for a new machine, annual operating costs or relocation costs.

\subsection{Membership Function Derivation}

In the fuzzy linear program it is known that both the demand and machine capacity are not exact but are within a specified tolerance. For this model it is assumed that the part 
demand forecasted in the crisp model is on the high end. Therefore, the actual demand may be lower than originally predicted. This results in the relaxing of the crisp demand constraints and the requirement that membership functions be developed to make them fuzzy.

Conversely, the machine capacity used in the crisp model is assumed to be lower than is actually available. Therefore, there may be more capacity than originally thought. This results in the relaxing of the crisp machine capacity constraints and the requirement that membership functions be developed to make them fuzzy.

A good objective to achieve may not be to minimize costs but to stay under a predetermined budget. Therefore, a goal to substantially be under budget is used as the objective. The forecasted budget used in the examples provided in this paper is the objective function value obtained from the crisp model solutions. This results in the tightening of the crisp objective function and the requirement that a membership function be developed to make it fuzzy.

\subsubsection{Membership Functions}

The membership function (shown graphically in Figure 3.1a) which is used to represent the fuzzy objective function is as follows (representing (3.1)): 


$$
\begin{aligned}
& 1 \\
& \text { if } \Sigma\left(D_{g h}+C_{p k m}\right) Y_{p k n g h ~} \leq z_{0}-p_{0} \\
& \mu_{0}(Y)=\quad z_{0}-\Sigma\left(D_{g l}+C_{p k m}\right) Y_{p k m g h} \quad \text { if } z_{0}-p_{0}<\Sigma\left(D_{g h l}+C_{p k m ! n}\right) Y_{p k m g l} \leq z_{0} \\
& p_{0} \\
& 0
\end{aligned}
$$

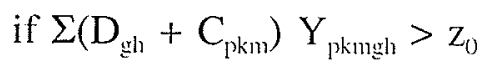

where $z_{0}$ is the optimal objective function value obtained from the crisp model.

The membership function (shown graphically in Figure $3.1 \mathrm{~b}$ ) which is used to represent the fuzzy demand is as follows (representing (3.2)):

$$
\begin{array}{ll}
\mu_{i}(Y)=\frac{1+\sum Y_{p / \text { mgl }}-D_{p}}{p_{i}} & \text { if } \Sigma Y_{p / \text { mgh }} \geq D_{p} \\
0 & \text { if } D_{p}-p_{i} \leq \Sigma Y_{p / \text { migh }} \\
\text { for } p=i=1,2, \ldots, P . & \text { if } \Sigma Y_{p / \text { mgl }}<D_{p}-p_{i}
\end{array}
$$

To simplify the process of making machine capacity fuzzy (to avoid fuzzy coefficients), equation (3.3) is split into two equivalent equations (3.9) and (3.10).

$$
\sum_{p} \sum_{k} \sum_{g} \sum_{h} t_{p k m} Y_{p k m g h} \leq T_{m} \quad \forall m
$$




$$
\sum_{p} \sum_{k} \sum_{h} Y_{p k m g h} \leq M Y_{m g} \quad \forall m, g
$$

where $M$ is a large number.

The membership function (shown graphically in Figure 3.1c) which is used to represent fuzzy machine capacity is as follows (representing (3.9)):

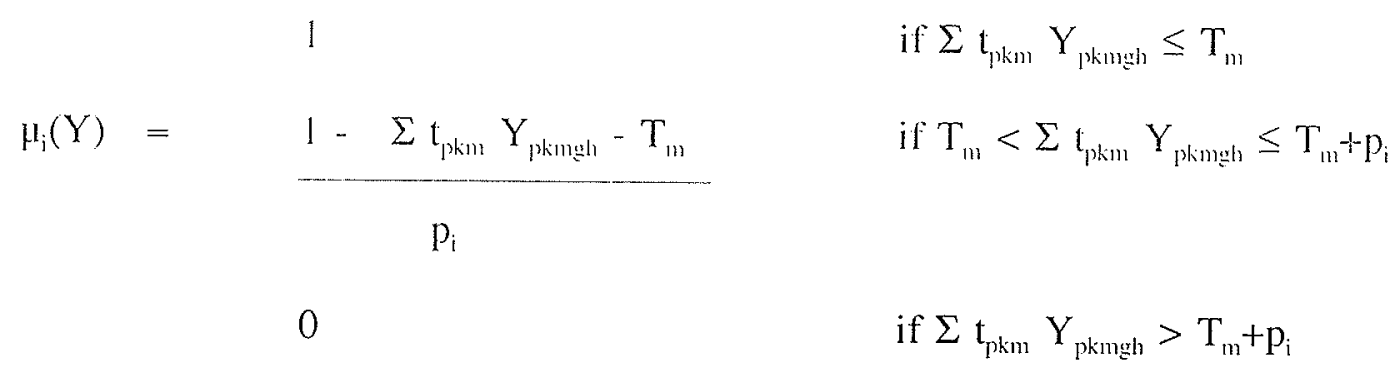

for $\mathrm{m}=1,2, \ldots, \mathrm{M}$

$\mathrm{i}=\mathrm{P}, \mathrm{P}+1, \ldots, \mathrm{P}+\mathrm{M}$.

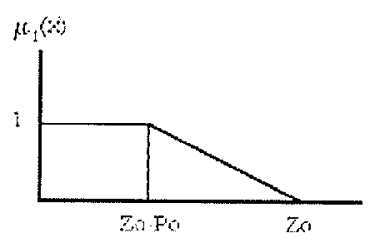

(a)

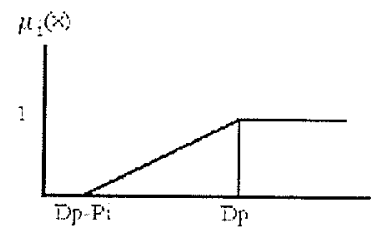

(b)

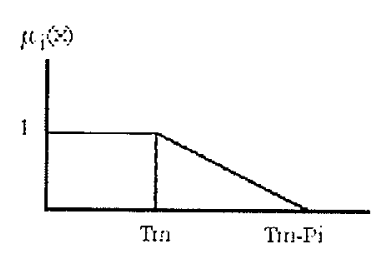

(c)

Figure 3.1: Membership Function Representations 


\subsection{Fuzzy Mathematical Model}

The fuzzy mathematical model is now presented. The objective function is to Maximize the Minimum $\left\{\mu_{0}(Y), \ldots, \mu_{\mathrm{P}+\mathrm{M}}(\mathrm{Y})\right\}$. To transform the objective function into a linear programming problem, set $\lambda \leq \mu_{\mathrm{i}}(\mathrm{Y}), \mathrm{i}=0,1, \ldots, \mathrm{P}+\mathrm{M}$ and bring the membership functions into the constraints and then set each of them $\geq \lambda$. Therefore, the objective function is represented by (3.11).

MAXIMIZE $\lambda$

subject to (3.4)-(3.8) and (3.10) plus,

$$
\begin{gathered}
\sum_{p} \sum_{k} \sum_{m} \sum_{g} \sum_{h}\left(D_{g h}+C_{p k m}\right) Y_{p k m g h}+p_{0} \lambda \leq z_{0} \\
\sum_{m} \sum_{g} \sum_{h} Y_{p l m g h}-p_{i} \lambda \geq D_{p}-p_{i} \quad \forall p \\
\sum_{p} \sum_{k} \sum_{g} \sum_{h} t_{p k m} Y_{p k m g h}+p_{i} \lambda \leq T_{m}+p_{i} \quad \forall m
\end{gathered}
$$

In the fuzzy model, constraints (3.4)-(3.8) of the crisp model and (3.10) remain valid and unchanged. However, the objective function (3.1), the demand constraints (3.2) and the machine capacity constraints (3.9) must be modified to reflect their membership functions. 
Constraint (3.12) of the fuzzy model represents the membership function of the fuzzy objective function and is achieved by setting the membership function $\mu_{0}(Y) \geq \lambda$. The second set of constraints (3.13) represent the membership functions of the fuzzy demand constraints and is achieved by setting the demand membership functions $\mu_{\mathrm{i}}(\mathrm{Y}) \geq \lambda, \mathrm{i}=$ $1,2, \ldots$, P. Similarly, we obtain the third set of constraints (3.14) which represent the membership functions of the fuzzy machine capacity constraints and is achieved by setting the machine capacity membership functions $\mu_{i}(Y) \geq \lambda, i=P+1, P+2, \ldots, P+M$.

\subsection{Illustrative Examples And Discussion}

In this section a number of examples are presented to illustrate the application of the mathematical models and their ability to obtain different solutions for crisp and fuzzy input parameters. All problems were solved using the Hyperlindo software package on a PC $486 / 33 \mathrm{MHz}$.

Consider a small cellular manufacturing environment such as the one shown in Figure 3.2. In this layout there are two cells each containing four machines which occupy different locations (locations are indicated in the boxes). The cost of moving a part between locations of the same and different cells is provided in a cost matrix given in Table 3.1.

Table 3.2 shows the demand for each part. The cost/unit and time/unit of performing each part's required operation on each machine is given in Table 3.3. Each machine has 
an operating time capacity of 124,800 minutes.

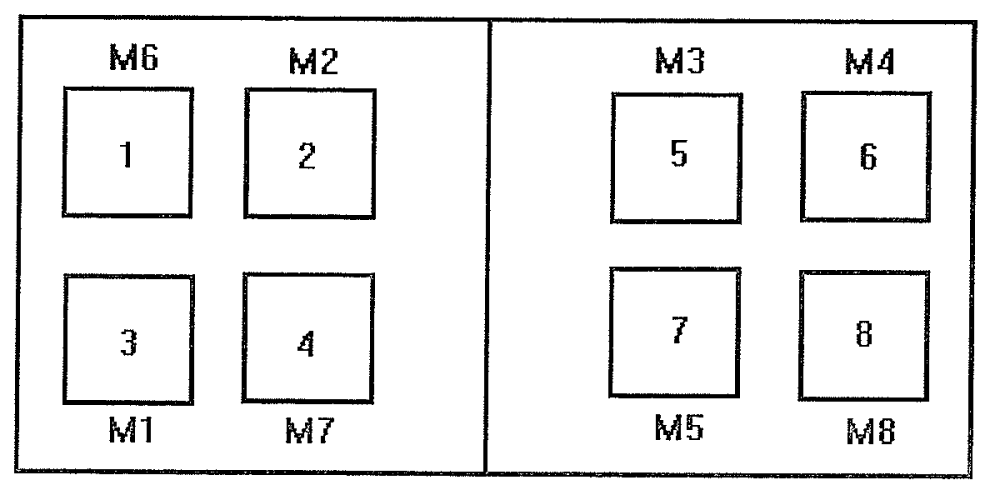

Figure 3.2: Initial Layout

For every example, it is assumed that machines $6,2,3$ and 8 cannot be moved due to size restrictions or for some other reason which makes relocation impractical. However, the remaining four machines can be relocated to any of the four remaining locations. Given this information, find the optimal machine layout and parts assignment which will minimize the sum of the material handling and processing costs.

\subsubsection{Example 3.1}

The first example is presented to show how the process operates under crisp demand and machine capacity. The resulting costs and machine placements are summarized in Table 3.8. The parts assignment for this given example is shown in Table 3.4. The total cost of production is $\$ 85,855$. In order to satisfy the demand, parts 2 and 8 require intercell 
moves (Table 3.4). However, the intercell moves for the 52 pieces of part 2 and the 20 pieces of part 8 can be attributed to capacity limitations of machines 2 and 4 .

\subsubsection{Example 3.2}

This example is identical to Example 3.1 except that the objective function, the demand and machine capacity are assumed to have a 5\% tolerance level each. In other words, the estimates for these are known to be within a $5 \%$ tolerance range. Using this data, it was found that a $\lambda$ of 0.556 was achieved. This means that for the given uncertainty the solution will be optimal with a level of certainty of $55.6 \%$. The new cost of production, shown in Table 3.8 , is $\$ 83,468$. Both the material handling and processing costs decreased over the crisp case due to the fact that less parts are produced.

A change in the parts assignment also occurred as evidenced by comparing Tables 3.4 and 3.5. Major changes occurred in the part flow of parts 1,2 and 8. This part assignment change occurs because the machine capacity is increased while the number of parts to produce is decreased. The more efficient machines are now capable of producing an even larger portion of the part demand. By reducing the total production by 104 parts, the material handling costs were reduced by $\$ 897$ while the processing costs were reduced by $\$ 1,490$. 
Figure 3.3 shows how the level of certainty relates to the tolerance level. As the tolerance level increases the level of confidence decreases. By examining this figure, one can not only determine the tolerance level required to achieve a certain level of confidence in the solution but also what levels of confidence are obtainable given the tolerance levels.

Figure 3.4 shows the obtainable levels of confidence for varying tolerance levels on the objective function $(1-5 \%)$ while the tolerances on demand and machine capacity are held constant $(5 \%)$. This figure shows that as the tolerance on the objective function decreases the level of confidence increases.

\subsubsection{Example 3.3}

In this example all input data remains the same as in Example 3.1 except for the demand for part 5 which has doubled to 110 units. The crisp model is again solved first. Table 3.6 shows the parts assignment. As can be seen in Table 3.8, machine relocation occurred with machines 1, 4 and 5 changing locations. This leads to a total cost of production of $\$ 89,061$. With the increase in demand, machine 8 now assumes an increased workload. It also has a high volume of flow with machine 4 and, consequently, are moved closer together. 


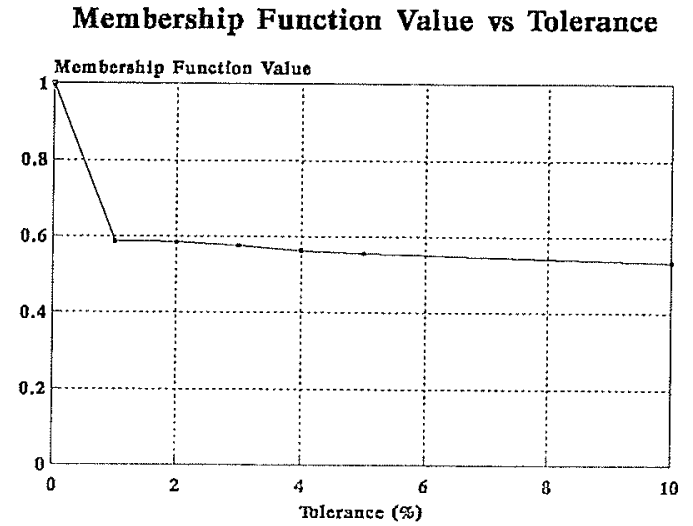

Figure 3.3
Membership Function Value vs Tolerance

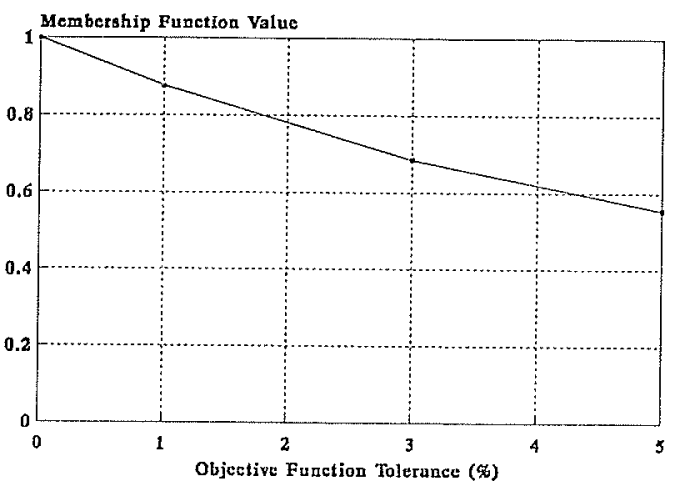

Figure 3.4

\subsubsection{Example 3.4}

The model in Example 3.3 is solved under the assumptions that the objective function, part demand and machine capacity are fuzzy. When solved under these fuzzy assumptions a total cost of production of $\$ 86,411$ was achieved, a difference of $\$ 2,650$ as compared to the crisp case. A $\lambda$ of 0.595 was achieved. This means that for the given uncertainty of $5 \%$ the solution will be optimal with a level of certainty of $59.5 \%$.

As indicated in Example 3.3 machines 1, 4 and 5 were relocated. However, under fuzzy considerations the machines were not relocated, as shown in Table 3.8. With the uncertainty of the demand and machine capacity, machine relocation did not occur. Consequently, the lack of relocating machines accounts for a vastly different part assignment as evidenced when examining Tables 3.6 and 3.7 . 


\subsection{Summary}

In this chapter crisp and fuzzy mathematical models were presented. The purpose of the models are to form cells; more specifically, to determine part assignment and machine placement. The models trade-off the cost of intercell and intracell movement with processing costs. A fuzzy mathematical model has been presented to determine the optimal cell formation under fuzzy machine capacity and part demand. It has been shown that solutions obtained from certain or crisp data and uncertain or fuzzy data differ. Therefore, in addition to cost trade-offs, the exactness of the data used must also be

considered. Several examples accompany the models to show how the machine placement and part assignments change as the input parameters change. 
Table 3.1: Cost of Moving One Part Between Locations

\begin{tabular}{|c|c|c|c|c|c|c|c|c|c|c|c|}
\hline & \multicolumn{10}{|c|}{ From Location } \\
\hline & & 0 & 1 & 2 & 3 & 4 & 5 & 6 & 7 & 8 & 9 \\
\hline \multirow{10}{*}{$\begin{array}{c}\text { To } \\
\text { Location }\end{array}$} & 0 & 0 & 0 & 0 & 0 & 0 & 0 & 0 & 0 & 0 & 0 \\
\hline & 1 & 0 & 0 & 3 & 3 & 6 & 11 & 14 & 14 & 17 & 0 \\
\hline & 2 & 0 & 3 & 0 & 6 & 3 & 8 & 11 & 11 & 14 & 0 \\
\hline & 3 & 0 & 3 & 6 & 0 & 3 & 14 & 17 & 11 & 14 & 0 \\
\hline & 4 & 0 & 6 & 3 & 3 & 0 & 11 & 14 & 8 & 11 & 0 \\
\hline & 5 & 0 & 11 & 8 & 14 & 11 & 0 & 3 & 3 & 6 & 0 \\
\hline & 6 & 0 & 14 & 11 & 17 & 14 & 3 & 0 & 6 & 3 & 0 \\
\hline & 7 & 0 & 14 & 11 & 11 & 8 & 3 & 6 & 0 & 3 & 0 \\
\hline & 8 & 0 & 17 & 14 & 14 & 11 & 6 & 3 & 3 & 0 & 0 \\
\hline & 9 & 0 & 0 & 0 & 0 & 0 & 0 & 0 & 0 & 0 & 0 \\
\hline
\end{tabular}

Where locations 0 and 9 are dummy locations and have zero cost.

Table 3.2: Part Demand ${ }^{1}$

\begin{tabular}{|c|c|c|c|c|c|c|c|c|}
\hline & \multicolumn{8}{|c|}{ Part } \\
\cline { 2 - 9 } & 1 & 2 & 3 & 4 & 5 & 6 & 7 & 8 \\
\hline Demand & 100 & 700 & 800 & 600 & 55 & 900 & 700 & 900 \\
\hline
\end{tabular}


Table 3.3: Cost/Time(min) per Part Operation for each Machine'

\begin{tabular}{|c|c|c|c|c|c|c|c|c|c|}
\hline \multirow{2}{*}{ Part } & \multirow{2}{*}{ Operation } & \multicolumn{8}{|c|}{ Machine } \\
\hline & & 1 & 2 & 3 & 4 & 5 & 6 & 7 & 8 \\
\hline \multirow{3}{*}{1} & 1 & $5 / 50$ & $5 / 50$ & & & & & & \\
\hline & 2 & $9 / 90$ & $9 / 90$ & & & & $4 / 80$ & & \\
\hline & 3 & & & & & & & $14 / 70$ & $14 / 70$ \\
\hline \multirow{3}{*}{2} & 1 & & & & & $7.5 / 75$ & & & \\
\hline & 2 & & & & $8 / 40$ & & & & \\
\hline & 3 & $3 / 60$ & $3 / 60$ & $1 / 20$ & & & & & \\
\hline \multirow{2}{*}{3} & 1 & & & & & & & $12 / 60$ & $12 / 60$ \\
\hline & 2 & $6 / 60$ & $6 / 60$ & $5=$ & & & $2.5 / 50$ & & \\
\hline \multirow{2}{*}{4} & 1 & & & $4 / 80$ & & & & & \\
\hline & 2 & & & & & $6 / 80$ & & & \\
\hline \multirow{3}{*}{5} & 1 & $8.9 / 89$ & $8.9 / 89$ & & & & & & \\
\hline & 2 & & & & $15 / 75$ & & $30 / 140$ & & \\
\hline & 3 & & & & & & & $14 / 70$ & $14 / 70$ \\
\hline \multirow{2}{*}{6} & 1 & & & & & & $2.5 / 50$ & & \\
\hline & 2 & 9/90 & $9 / 90$ & & & & & & \\
\hline \multirow{2}{*}{7} & 1 & & & $3.5 / 70$ & & & & & \\
\hline & 2 & $4 / 40$ & $4 / 40$ & & & & & & \\
\hline \multirow{3}{*}{8} & 1 & & & & & & & $4 / 80$ & $4 / 80$ \\
\hline & 2 & & & & $3 / 15$ & & $4 / 80$ & & \\
\hline & 3 & & & & $9 / 90$ & $5 / 50$ & & & \\
\hline
\end{tabular}

Where no entry indicates the machine cannot perform that operation.

${ }^{1}$ Data was taken from Sankaran and Kasilingam. (1993), 'On Cell Size and Machine Requirements Planning in Group Technology Systems', European Journal of Operation Research 69, 373-383. with modifications to allow for more alternate part routings. 
Table 3.4: Part AssignmentMachine Location for Example 3.1

\begin{tabular}{|c|c|c|c|c|c|c|c|c|c|c|c|c|c|c|c|}
\hline \multirow{5}{*}{$\begin{array}{c}\text { Part } \\
\text { (Demand) } \\
\text { (Quantity } \\
\text { Produced) }\end{array}$} & \multirow{5}{*}{$\begin{array}{l}\text { Oper- } \\
\text { ation }\end{array}$} & \multicolumn{8}{|c|}{ Location } & & & & & & \\
\hline & & \multicolumn{4}{|c|}{ Cell 1} & \multicolumn{4}{|c|}{ Cell 2} & & & & & & \\
\hline & & 1 & 2 & 3 & 4 & 5 & 6 & 7 & 8 & \multirow{2}{*}{\multicolumn{3}{|c|}{ Actual Costs (\$) }} & \multirow{2}{*}{\multicolumn{3}{|c|}{$\begin{array}{l}\text { Minimum Achievable Costs } \\
\text { (\$) }\end{array}$}} \\
\hline & & \multicolumn{8}{|c|}{ Machine } & & & & & & \\
\hline & & 6 & 2 & 7 & 4 & 3 & 1 & 5 & 8 & Intracell & Intercell & Process & Intracell & Intercell & Process \\
\hline \multirow{3}{*}{$\begin{array}{c}1 \\
(100) \\
(100)\end{array}$} & 1 & & & & & & 100 & & & \multirow{3}{*}{300} & \multirow{3}{*}{0} & \multirow{3}{*}{2800} & \multirow{3}{*}{300} & \multirow{3}{*}{0} & \multirow{3}{*}{2300} \\
\hline & 2 & & & & & & 100 & & & & & & & & \\
\hline & 3 & & & & & & & & 100 & & & & & & \\
\hline \multirow{3}{*}{$\begin{array}{c}2 \\
(700) \\
(700)\end{array}$} & 1 & & & & & & & 700 & & \multirow{3}{*}{$19+4$} & \multirow{3}{*}{6172} & \multirow{3}{*}{12846} & \multirow{3}{*}{2100} & \multirow{3}{*}{5600} & \multirow{3}{*}{11550} \\
\hline & 2 & & & & 700 & & & & & & & & & & \\
\hline & 3 & & 648 & & & 52 & & & & & & & & & \\
\hline \multirow{2}{*}{$\begin{array}{c}3 \\
(800) \\
(800)\end{array}$} & 1 & & & 800 & & & & & & \multirow[b]{2}{*}{2400} & \multirow[b]{2}{*}{0} & \multirow[b]{2}{*}{11600} & \multirow[b]{2}{*}{2400} & \multirow[b]{2}{*}{0} & \multirow[b]{2}{*}{11600} \\
\hline & 2 & 800 & & & & & & & & & & & & & \\
\hline \multirow{2}{*}{$\begin{array}{c}4 \\
(600) \\
(600)\end{array}$} & 1 & & & & & 600 & & & & \multirow[b]{2}{*}{1800} & \multirow[b]{2}{*}{0} & & & & \\
\hline & 2 & & & & & & & 600 & & & & 6000 & 1800 & 0 & 6000 \\
\hline & 1 & & 55 & & & & & & & & & & & & \\
\hline (55) & 2 & & & & 55 & & & & & 330 & 0 & 2085 & 330 & 0 & 2085 \\
\hline & 3 & & & 55 & & & & & & & & & & & \\
\hline
\end{tabular}


Table 3.4: Part AssignmentMachine Location for Example 3.1 Continued

\begin{tabular}{|c|c|c|c|c|c|c|c|c|c|c|c|c|c|c|c|}
\hline \multirow{2}{*}{$\begin{array}{c}6 \\
(900) \\
(900)\end{array}$} & 1 & 900 & & & & & & & & \multirow[b]{2}{*}{2700} & \multirow[b]{2}{*}{0} & \multirow[b]{2}{*}{10350} & \multirow[b]{2}{*}{2700} & \multirow[b]{2}{*}{0} & \multirow[b]{2}{*}{10350} \\
\hline & 2 & & 900 & & & & & & & & & & & & \\
\hline \multirow{2}{*}{$\begin{array}{c}7 \\
(700) \\
(700)\end{array}$} & 1 & & & & & 700 & & & & \multirow[b]{2}{*}{2100} & \multirow[b]{2}{*}{0} & \multirow[b]{2}{*}{52.50} & \multirow[b]{2}{*}{2100} & \multirow[b]{2}{*}{0} & \multirow[b]{2}{*}{5250} \\
\hline & 2 & & 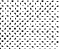 & & & & 700 & & & & & & & & \\
\hline \multirow{3}{*}{$\begin{array}{c}8 \\
(900) \\
(900)\end{array}$} & 1 & & & 900 & & & & & & \multirow{3}{*}{2700} & \multirow{3}{*}{160} & \multirow{3}{*}{14320} & \multirow{3}{*}{2700} & \multirow{3}{*}{0} & \multirow{3}{*}{10800} \\
\hline & 2 & : & & & 900 & & & & & & & & & & \\
\hline & 3 & & & & 880 & & & 20 & & & & & & & \\
\hline \multicolumn{2}{|c|}{$\begin{array}{l}\text { Remaining Machine } \\
\text { Capacity (minutes) }\end{array}$} & 39800 & 0 & 950 & 0 & 26760 & 82800 & 23300 & 117800 & & & & & & \\
\hline
\end{tabular}

"Indicates the minimum processing and material handling costs that could be achieved for the obtained machine layout if machine capacity is neglected.

- Shaded cells indicate that the operation could be performed on the machine but was chosen not to because it would result in a less than optimal solution.

- Machines numbers in bold identify those machines that cannot be relocated. 
Table 3.5: Part AssignmentMachine Location for Example 3.2

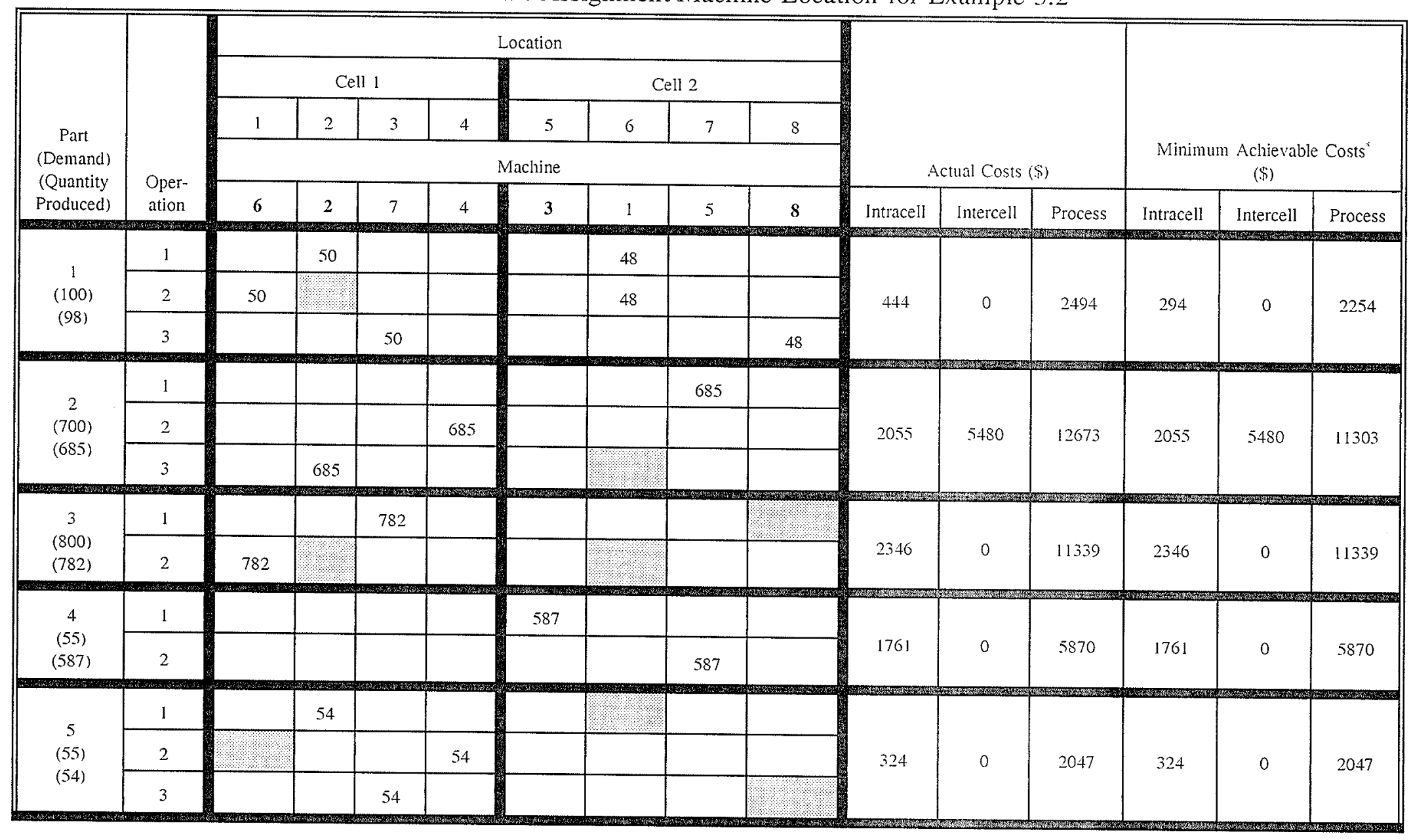


Table 3.5: Part AssignmentMachine Location for Example 3.2 Continued

\begin{tabular}{|c|c|c|c|c|c|c|c|c|c|c|c|c|c|c|c|}
\hline \multirow{3}{*}{$\begin{array}{c}6 \\
(900) \\
(880)\end{array}$} & & & & & & & & & II & \multirow[b]{3}{*}{2640} & \multirow[b]{3}{*}{0} & \multirow[b]{3}{*}{10120} & \multirow[b]{3}{*}{2640} & \multirow[b]{3}{*}{0} & \multirow[b]{3}{*}{10120} \\
\hline & 1 & 880 & & & & & & & & & & & & & \\
\hline & 2 & & 880 & & & & & & & & & & & & \\
\hline \multirow{2}{*}{$\begin{array}{c}7 \\
(700) \\
(685)\end{array}$} & 1 & & & & & 685 & & & & \multirow[b]{2}{*}{2055} & \multirow[b]{2}{*}{0} & \multirow[b]{2}{*}{5138} & \multirow[b]{2}{*}{2055} & \multirow[b]{2}{*}{0} & \multirow[b]{2}{*}{5138} \\
\hline & 2 & & & & & & 685 & & & & & & & & \\
\hline \multirow{3}{*}{$\begin{array}{c}8 \\
(900) \\
(880)\end{array}$} & 1 & & & 880 & & & & & & \multirow{3}{*}{2640} & \multirow{3}{*}{0} & \multirow{3}{*}{14080} & \multirow{3}{*}{2640} & \multirow{3}{*}{0} & \multirow{3}{*}{10560} \\
\hline & 2 & 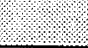 & & & 880 & & & & & & & & & & \\
\hline & 3 & & & & 880 & & & & & & & & & & \\
\hline \multicolumn{2}{|c|}{$\begin{array}{l}\text { Remaining Machine } \\
\text { Capacity (minutes) }\end{array}$} & 40471 & 0 & 2971 & 3721 & 32661 & 93451 & 39236 & 124211 & & & & & & \\
\hline
\end{tabular}

"Indicates the minimum processing and material handling costs that could be achieved for the obtained machine layout if machine capacity is neglected.

- Shaded cells indicate that the operation could be performed on the machine but was chosen not to because it would result in a less than optimal solution.

- Machines numbers in bold identify those machines that cannot be relocated. 
Table 3.6: Part Assignment Machine Location for Example 3.3

\begin{tabular}{|c|c|c|c|c|c|c|c|c|c|c|c|c|c|c|c|}
\hline \multirow{5}{*}{$\begin{array}{c}\text { Part } \\
\text { (Demand) } \\
\text { (Quantity } \\
\text { Produced) }\end{array}$} & \multirow{5}{*}{$\begin{array}{l}\text { Oper- } \\
\text { ation }\end{array}$} & \multicolumn{8}{|c|}{ Location } & & & & & & \\
\hline & & \multicolumn{4}{|c|}{ Cell 1} & \multicolumn{4}{|c|}{ Cell 2} & & & & & & \\
\hline & & 1 & 2 & 3 & 4 & 5 & 6 & 7 & 8 & \multirow{2}{*}{\multicolumn{3}{|c|}{ Actual Costs (\$) }} & \multirow{2}{*}{\multicolumn{3}{|c|}{$\begin{array}{l}\text { Minimum Achievable Costs } \\
(\$)\end{array}$}} \\
\hline & & \multicolumn{8}{|c|}{ Machine } & & & & & & \\
\hline & & 6 & 2 & 7 & 1 & 3 & 5 & 4 & 8 & Intracell & Intercell & Process & Intracell & Intercell & Process \\
\hline \multirow{3}{*}{$\begin{array}{c}1 \\
(100) \\
(100)\end{array}$} & 1 & & 100 & & & & & & & \multirow{3}{*}{600} & \multirow{3}{*}{0} & \multirow{3}{*}{2300} & \multirow{3}{*}{300} & \multirow{3}{*}{0} & \multirow{3}{*}{2300} \\
\hline & 2 & 100 & & & & & & & & & & & & & \\
\hline & 3 & & & 100 & & & & & & & & & & & \\
\hline \multirow{3}{*}{$\begin{array}{c}2 \\
(700) \\
(700)\end{array}$} & 1 & & & & & & 700 & & & \multirow{3}{*}{6300} & \multirow{3}{*}{0} & \multirow{3}{*}{11550} & \multirow{3}{*}{4200} & \multirow{3}{*}{0} & \multirow{3}{*}{11550} \\
\hline & 2 & & & & & & & 700 & & & & & & & \\
\hline & 3 & & & & & 700 & & & & & & & & & \\
\hline \multirow{2}{*}{$\begin{array}{c}3 \\
(800) \\
(800)\end{array}$} & 1 & & & 800 & & & & & & \multirow[b]{2}{*}{2400} & \multirow[b]{2}{*}{0} & \multirow[b]{2}{*}{11600} & \multirow[b]{2}{*}{2400} & \multirow[b]{2}{*}{0} & \multirow[b]{2}{*}{11600} \\
\hline & 2 & 800 & & & & & & & & & & & & & \\
\hline \multirow{2}{*}{$\begin{array}{c}4 \\
(600) \\
(600)\end{array}$} & 1 & & & & & 600 & & & & \multirow[b]{2}{*}{1800} & \multirow[b]{2}{*}{0} & & & & \\
\hline & 2 & & & & & & 600 & & & & & 6000 & 1800 & 0 & 6000 \\
\hline 5 & 1 & & & & 110 & & & & & & & & & & \\
\hline (110) & 2 & & & & & & & 110 & & 330 & 880 & 4169 & 990 & 0 & 4169 \\
\hline & 3 & & & & & & & & 110 & & & & & & \\
\hline
\end{tabular}


Table 3.6: Part Assignment Machine Location for Example 3.3 Continued

\begin{tabular}{|c|c|c|c|c|c|c|c|c|c|c|c|c|c|c|c|}
\hline \multirow{2}{*}{$\begin{array}{c}6 \\
(900) \\
(900)\end{array}$} & 1 & 900 & & & & & & & & \multirow[b]{2}{*}{2700} & \multirow[b]{2}{*}{0} & \multirow[b]{2}{*}{11250} & \multirow[b]{2}{*}{2700} & \multirow[b]{2}{*}{0} & \multirow[b]{2}{*}{10350} \\
\hline & 2 & & 900 & & & & & & & & & & & & \\
\hline \multirow{2}{*}{$\begin{array}{c}7 \\
(700) \\
(700)\end{array}$} & 1 & & & & & 700 & & & & \multirow[b]{2}{*}{0} & \multirow[b]{2}{*}{5600} & \multirow[b]{2}{*}{5250} & \multirow[b]{2}{*}{0} & \multirow[b]{2}{*}{5600} & \multirow[b]{2}{*}{5250} \\
\hline & 2 & & 700 & & & & & & & & & & & & \\
\hline \multirow{3}{*}{$\begin{array}{c}8 \\
(900) \\
(900)\end{array}$} & 1 & & & & & & & & 900 & \multirow{3}{*}{3096} & \multirow{3}{*}{0} & \multirow{3}{*}{7377} & \multirow{3}{*}{2700} & \multirow{3}{*}{0} & \multirow{3}{*}{10800} \\
\hline & 2 & & & & & & & 900 & & & & & & & \\
\hline & 3 & & & & & & 66 & 834 & & & & & & & \\
\hline \multicolumn{2}{|c|}{$\begin{array}{l}\text { Remaining Machine } \\
\text { Capacity (minutes) }\end{array}$} & 31800 & 10800 & 69800 & 115010 & 13800 & 21000 & 0 & 45100 & & & & & & \\
\hline
\end{tabular}

"Indicates the minimum processing and material handling costs that could be achieved for the obtained machine layout if machine capacity is neglected.

- Shaded cells indicate that the operation could be performed on the machine but was chosen not to because it would result in a less than optimal solution.

- Machines numbers in bold identify those machines that cannot be relocated. 
Table 3.7: Part AssignmentMachine Location for Example 3.4

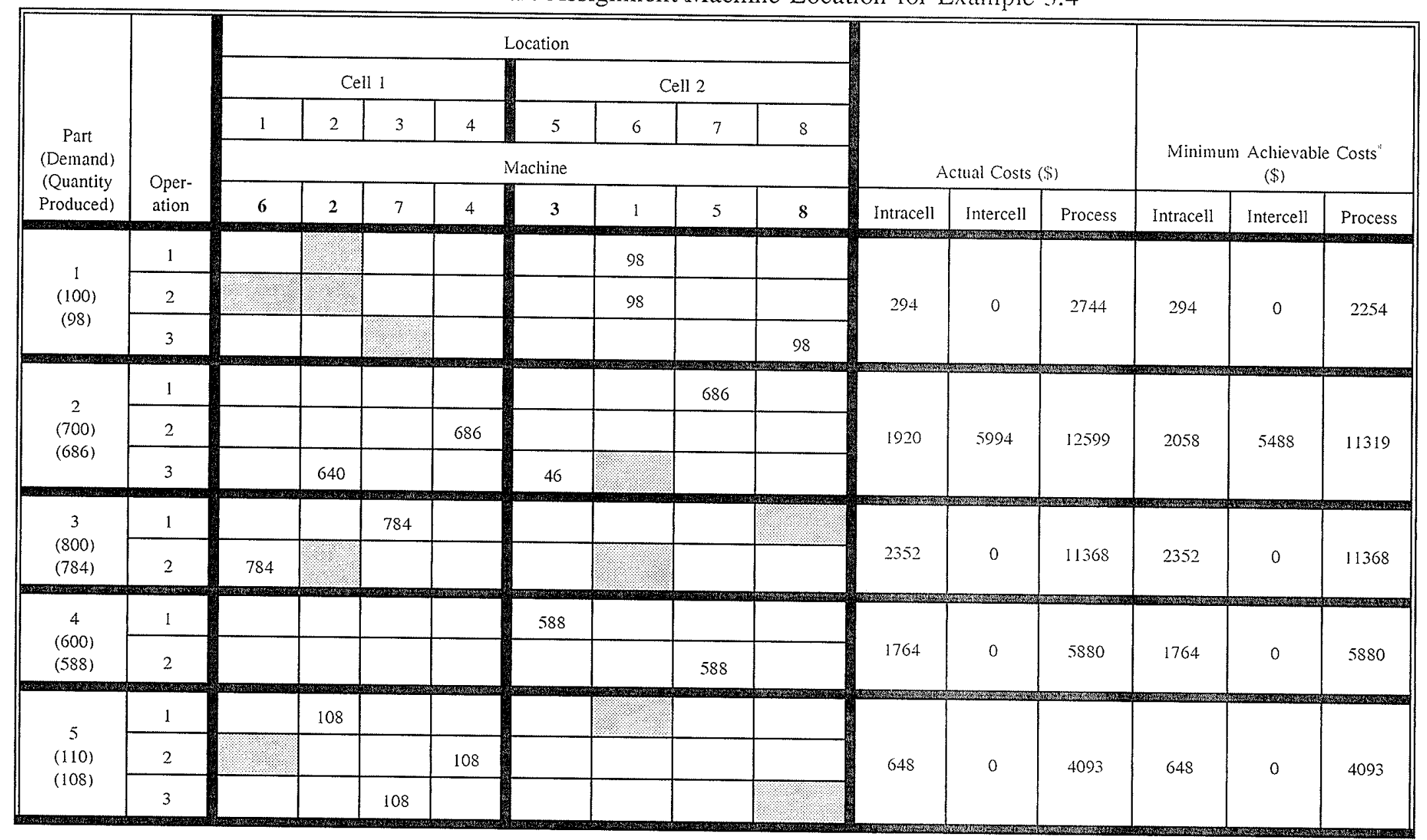


Table 3.7: Part AssignmentMachine Location for Example 3.4 Continued

\begin{tabular}{|c|c|c|c|c|c|c|c|c|c|c|c|c|c|c|c|}
\hline \multirow{2}{*}{$\begin{array}{c}6 \\
(900) \\
(882)\end{array}$} & 1 & 882 & & & & & & & & \multirow[b]{2}{*}{2646} & \multirow[b]{2}{*}{0} & \multirow[b]{2}{*}{10143} & \multirow[b]{2}{*}{2640} & \multirow[b]{2}{*}{0} & \multirow[b]{2}{*}{10143} \\
\hline & 2 & & 882 & & & & & & & & & & & & \\
\hline \multirow{2}{*}{$\begin{array}{c}7 \\
(700) \\
(686)\end{array}$} & 1 & & & & & 606 & & & & \multirow[b]{2}{*}{2058} & \multirow[b]{2}{*}{0} & \multirow[b]{2}{*}{5145} & \multirow[b]{2}{*}{2058} & \multirow[b]{2}{*}{0} & \multirow[b]{2}{*}{5145} \\
\hline & 2 & & & & & & 60 & & & & & & & & \\
\hline \multirow{4}{*}{$\begin{array}{c}3 \\
(800) \\
(882)\end{array}$} & & & & & & & & & & \multirow{5}{*}{2646} & \multirow{5}{*}{0} & \multirow{4}{*}{14076} & \multirow{5}{*}{2646} & \multirow{5}{*}{0} & \multirow{5}{*}{10584} \\
\hline & 1 & & & 882 & & & & & & & & & & & \\
\hline & 2 & & & & 882 & & & & & & & & & & \\
\hline & 3 & & & & 873 & & & 9 & & & & & & & \\
\hline 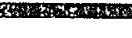 & & & & & & & & & & & & & & & \\
\hline \multicolumn{2}{|c|}{$\begin{array}{l}\text { Remaining Machine } \\
\text { Capacity (minutes) }\end{array}$} & 44027 & 0 & 2167 & 0 & 31347 & 86167 & 28837 & 120467 & & & & & & \\
\hline
\end{tabular}

* Indicates the minimum processing and material handling costs that could be achieved for the obtained machine layout if machine capacity is neglected.

- Shaded cells indicate that the operation could be performed on the machine but was chosen not to because it would result in a less than optimal solution.

- Machines numbers in bold identify those machines that cannot be relocated. 
Table 3.8: Summary of Results

\begin{tabular}{|c|c|c|c|c|c|}
\hline Example & $\lambda$ & $\begin{array}{l}\text { Machine } \\
\text { Location }\end{array}$ & $\begin{array}{c}\text { Objective } \\
\text { Function } \\
(\$)\end{array}$ & $\begin{array}{l}\text { Material } \\
\text { Handling } \\
\text { Costs }(\$)\end{array}$ & $\begin{array}{l}\text { Processing } \\
\text { Costs }(\$)\end{array}$ \\
\hline 3.1 & 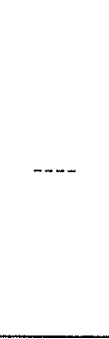 & $\begin{array}{l}M / C 1 \text { in LOC } 6 \\
M / C 2 \text { in LOC } 2 \\
M / C 3 \text { in LOC } 5 \\
M / C 4 \text { in LOC } 4 \\
M / C 5 \text { in LOC } 7 \\
M / C 6 \text { in LOC } 1 \\
M / C 7 \text { in LOC } 3 \\
M / C 8 \text { in LOC } 8\end{array}$ & 85,855 & 20,605 & 65,250 \\
\hline 3.2 & 0.556 & $\begin{array}{l}M / C 1 \text { in LOC } 6 \\
M / C 2 \text { in LOC } 2 \\
M / C 3 \text { in LOC } 5 \\
M / C 4 \text { in LOC } 4 \\
M / C 5 \text { in LOC } 7 \\
M / C 6 \text { in LOC } 1 \\
M / C 7 \text { in LOC } 3 \\
M / C 8 \text { in LOC } 8\end{array}$ & 83,468 & 19,708 & 63,760 \\
\hline 3.3 & ---- & $\begin{array}{l}M / C 1 \text { in LOC } 4 \\
M / C 2 \text { in LOC } 2 \\
M / C 3 \text { in LOC } 5 \\
M / C 4 \text { in LOC } 7 \\
M / C 5 \text { in LOC } 6 \\
M / C 6 \text { in LOC } 1 \\
M / C 7 \text { in LOC } 3 \\
M / C 8 \text { in LOC } 8\end{array}$ & 89,061 & 23,706 & 65,355 \\
\hline 3.4 & 0.595 & $\begin{array}{l}\text { M/C } 1 \text { in LOC } 6 \\
\text { M/C } 2 \text { in LOC } 2 \\
\text { M/C } 3 \text { in LOC } 5 \\
\text { M/C } 4 \text { in LOC } 4 \\
\text { M/C } 5 \text { in LOC } 7 \\
\text { M/C } 6 \text { in LOC } 1 \\
\text { M/C } 7 \text { in LOC } 3 \\
\text { M/C } 8 \text { in LOC } 8\end{array}$ & 86,411 & 20,362 & 66,048 \\
\hline
\end{tabular}




\subsection{NON-LINEAR CRISP AND FUZZY MATHEMATICAL MODELS}

For large numbers of integer variables, the computation time required by software packages, such as Hyperlindo, is quite large. Therefore, any reductions in computation time would be beneficial to the user. The focus of this chapter is to develop an alternate solution strategy that will solve problems in an efficient manner. Alternative non-linear mathematical formulations of the crisp and fuzzy models presented in Chapter 3 are developed. The non-linear form allows each model to be decomposed into two submodels; namely, a part allocation model and a machine location model. An iterative procedure is then introduced which utilizes these sub-models to converge to a solution in a substantially reduced computational time.

This chapter is organized as follows. Section 4.1 contains the crisp non-linear formulation while Section 4.2 contains the fuzzy non-linear mathematical model. The decomposition of the non-linear crisp and fuzzy mathematical models into part allocation and machine location models are presented in Sections 4.3 and 4.4, respectively. Section 4.5 details the iterative solution procedure. Section 4.6 gives examples of the iterative procedure and compares the results with those obtained with the linear models of Chapter 3. A summary is provided in Section 4.7. 


\subsection{Crisp Non-Linear Mathematical Model}

The mathematical model developed below is a non-linear representation of the crisp model of Section 3.2. The objective function (4.1) consists of two costs. The first term represents the material handling costs while the second term represents the processing costs.

$$
\text { MINIMIZE } \sum_{p} \sum_{k} \sum_{m} \sum_{g} \sum_{h}\left(D_{g h} Y_{m g} Y_{n h}+C_{p k m}\right) Y_{p k m n}
$$

Subject to (3.5), (3.6) and (3.8) of the crisp model plus,

$$
\begin{gathered}
\sum_{m} \sum_{n} Y_{p 1 m n} \geq D_{p} \quad \forall p \\
\sum_{p} \sum_{k} \sum_{n} t_{p k m} Y_{p k m n} \leq T_{m} \quad \forall m \\
\sum_{n} Y_{p, k-1, n m}=\sum_{n} Y_{p k m n} \quad \forall p, k, m \\
Y_{p k m n} \geq 0 \quad \forall p, k, m, n
\end{gathered}
$$

In the non-linear model, constraints (3.5), (3.6) and (3.8) of the crisp model remain valid and unchanged. This mathematical model consists of four additional sets of constraints. The first set of constraints (4.2) ensures that the demand for every part is met. The 
second set (4.3) ensures that the machining time available on each machine is not violated. The third set (4.4) is the flow equilibrium constraints. This ensures that the number of parts which enter a machine leave the machine and that each part receives all required operations. The final set are the non-negativity constraints represented by (4.5).

\subsection{Fuzzy Non-Linear Mathematical Model}

The mathematical model developed below is a non-linear representation of the fuzzy model of Section 3.4. The objective function is to Maximize the Minimum $\left\{\mu_{0}(Y), \ldots\right.$, $\left.\mu_{\mathrm{P}+\mathrm{M}}(\mathrm{Y})\right\}$. To transform the objective function into a linear programming problem, set $\lambda$ $\leq \mu_{1}(Y), \mathrm{i}=0,1, \ldots, \mathrm{P}+\mathrm{M}$ and bring the membership functions into the constraints and then set each of them $\geq \lambda$. Therefore, the objective function is represented by (4.6).

\section{MAXIMIZE $\lambda$}

Subject to (3.5), (3.6) and (3.8) of the crisp model plus,

$$
\begin{gathered}
\sum_{p} \sum_{k} \sum_{m} \sum_{g} \sum_{h}\left(D_{g h} Y_{m g} Y_{n h}+C_{p k m}\right) Y_{p k n n}+p_{0} \lambda \leq z_{0} \\
\sum_{m} \sum_{g} \sum_{h} Y_{p l m n}-p_{i} \lambda \geq D_{p}-p_{i} \quad \forall p
\end{gathered}
$$




$$
\begin{gathered}
\sum_{p} \sum_{k} \sum_{g} \sum_{h} t_{p k m} Y_{p k m n}+p_{i} \lambda \leq T_{m}+p_{i} \quad \forall m \\
\sum_{n} Y_{p, k-1, n m}=\sum_{n} Y_{p k m n} \quad \forall p, k, m \\
Y_{p k m n} \geq 0 \quad \forall p, k, m, n
\end{gathered}
$$

In the non-linear model, constraints (3.5), (3.6) and (3.8) of the crisp model remain valid and unchanged. As with the linear fuzzy mathematical model presented in Section 3.4 the constraints had to be modified to represent the corresponding membership functions. Constraint (4.7) of the fuzzy model represents the membership function of the fuzzy objective function and is achieved by setting the membership function $\mu_{0}(Y) \geq \lambda$. The second set (4.8) of constraints represent the membership functions of the fuzzy demand constraints and is achieved by setting the demand membership functions $\mu_{i}(Y) \geq \lambda, i=$ $1,2, \ldots$, P. Similarly, we obtain the third set (4.9) of constraints which represent the membership functions of the fuzzy machine capacity constraints and is achieved by setting the machine capacity membership functions $\mu_{i}(Y) \geq \lambda, i=P+1, P+2, \ldots, P+M$. The fourth set (4.10) is the flow equilibrium constraints. This ensures that the number of parts which enter a machine leave the machine and that each part receives all required operations. The final set are the non-negativity constraints represented by (4.11). 


\subsection{Part Allocation Mathematical Models}

In this section the first of the two sub-models are presented. The part allocation models assign every operation required in producing a part to individual machine(s) for a given machine layout. The part allocation model for the crisp case is presented first followed by part allocation model for the fuzzy case.

\subsubsection{Crisp Part Allocation Mathematical Model}

The crisp part allocation model is the first sub-model of the crisp non-linear model. It is used to determine the optimal part assignment for a given machine layout. The objective function (4.12) is similar to that of the crisp non-linear model (4.1) with the exception of the variable $X_{\text {mgnhl }}$ which replaces the term $Y_{m} * Y_{n l 1}$. For this model, the

variable $X_{m g n h}$ (machine layout) is known and is treated as a constant. The valid constraints for this model are (4.2)-(4.5) of the non-linear model.

$$
\text { MINIMIZE } \sum_{p} \sum_{k} \sum_{m} \sum_{g} \sum_{h}\left(D_{g h} X_{m g n h}+C_{p k m}\right) Y_{p k m n}
$$

Where $X_{\text {mgnh }}$ is a known constant for the part assignment model. 


\subsubsection{Fuzzy Part Allocation Mathematical Model}

The fuzzy part allocation model is the first sub-model of the fuzzy non-linear model. It is used to determine the optimal part assignment for a given machine layout. In this model the objective function (4.6) remains unchanged. However, constraint (4.7) is transformed into constraint (4.13) with the variable $X_{m g n h}$ replacing the term $Y_{m y} * Y_{n l l}$. As in the crisp part allocation model, the variable $\mathrm{X}_{\text {ngm }}$ is known and is treated as a constant. The valid constraints for this model are (4.8)-(4.11) of the fuzzy non-linear model and (4.13).

$$
\sum_{p} \sum_{k} \sum_{m} \sum_{g} \sum_{h}\left(D_{g h} X_{m g n h}+C_{p k n}\right) Y_{p k m n}+p_{0} \lambda \leq z_{0}
$$

Where $\mathrm{X}_{\mathrm{mgnhl}}$ is a known constant for the part assignment model.

\subsubsection{Crisp and Fuzzy Machine Location Mathematical Models}

The machine location model is the second sub-model for both the crisp and fuzzy nonlinear models. The same machine location model can be used for both crisp and fuzzy models because the fuzziness occurs with part demand and machine capacity and not with where the machines can be located. This model is used to determine the optimal machine layout for a given part assignment. The objective function (4.14) is the same as (4.12) 
with the exception that $Y_{\text {pknm }}$ (part assignment) is now known and $X_{\text {mgnl }}$ (machine location) is now unknown.

$$
\text { MINIMIZE } \sum_{p} \sum_{k} \sum_{m} \sum_{g} \sum_{h}\left(D_{g h} X_{m g n h}+C_{p k m}\right) Y_{p k m n}
$$

Where $Y_{p k m m}$ is a known constant for the machine location model.

The valid constraints for this model are (3.5), (3.6) and (3.8) of the crisp model plus,

$$
\begin{gathered}
X_{m g n h} \geq Y_{m g}+Y_{n h}-1 \quad \forall m, g, n, h \\
X_{m g n h} \leq Y_{m g} \quad \forall m, g, n, h \\
X_{m g n h}=0,1 \quad \forall m, g, n, h
\end{gathered}
$$

In the machine location model, constraints (3.5), (3.6) and (3.8) of the crisp model remain valid and unchanged. This mathematical model consists of three additional sets of constraints. The first two sets (4.15) and (4.16) relate the variable $X_{\text {mgnh }}$ to the variables $Y_{m g}$ and $Y_{m l 1}$. The third set (4.17) are the binary constraints and are required to ensure that the variables assume 0 or 1 values only. 


\subsection{Iterative Solution Strategy}

To achieve a more practical computation time an iterative solution procedure is introduced. The iterative procedure utilizes the decomposed non-linear mathematical model; namely, the part allocation and machine location models to converge to a solution. The iterative procedure begins by selecting an initial machine layout. The initial layout can either be randomly chosen or the existing layout can be used. The rest of the procedure is as follows:

STEP / ${ }^{\text {th: }}$ the part allocation model is solved, yielding the optimal part assignment for the given layout.

STEP $2^{\mathrm{b}}$ : the part assignment obtained from the part allocation model is used as input for the machine location model. The machine location model is then solved, yielding the optimal machine layout for the given part assignment.

This iterative procedure is repeated until the solutions obtained from each model do not change.

\footnotetext{
" indicates the iteration number
} 


\subsection{Illustrative Examples}

Several examples are now used to demonstrate the iterative procedure. Unless otherwise noted, the data used as input for these examples is taken from Example 3.1. The results, along with computational experience, obtained from using the iterative procedure are compared to those obtained by the linear mathematical models of Chapter 3 . All models were solved using the Hyperlindo software package on a PC $486 / 33 \mathrm{MHz}$.

\subsubsection{Example 4.1}

Starting with the randomly chosen machine layout shown in Table 4.1 and using the part allocation and machine location models, the following iterations are obtained.

Step 1 ${ }^{1}$ : The part assignment model is solved using the machine layout (Table 4.1). The obtained part assignment is shown in Table 4.2. The resulting objective function is $\$ 90,030$.

Step $2^{1}$ : Using the part assignment obtained from Step $1^{1}$ as input data for the machine location model, the new machine layout (Table 4.3) is obtained. The resulting objective function value is $\$ 86,035$. Since the machine location is not the same as the input in Step $1^{1}$, proceed to Step $1^{2}$ using the machine layout obtained in Step $2^{1}$. 
Step 12: The machine layout obtained from Step $2^{1}$ (Table 4.3) is used as input data for the second part assignment model iteration. An objective function value of $\$ 85,855$ is obtained and the resulting part assignment is shown in Table 4.4.

Continuing the process results in the repetition of the solutions obtained in Steps $1^{2}$ and $2^{1}$. Therefore, the best machine layout and part assignment found using the iterative procedure are shown in Tables 4.3 and 4.4, respectively. Comparing the results to the one obtained from Example 3.1, it is shown that the two solutions are identical.

\subsubsection{Example 4.2}

Example 3.1 is again solved using the iterative procedure except this time a different initial machine layout (Table 4.5) is used. Starting with another randomly chosen layout provided in Table 4.5 and using the part assignment and machine location models from the iterative procedure the following iterations are obtained.

Step 1': The part assignment model is solved using the machine layout (Table 4.5) for input. The obtained part assignment for this given example is shown in Table 4.6. The resulting objective function is $\$ 102,249$.

Step $2^{1}$ : Using the part assignment obtained from Step $1^{1}$ (Table 4.6) as input data for 
the machine location model, the new machine layout (Table 4.7) is obtained. The resulting objective function value is $\$ 96,738$. Since the machine location is not the same as the input in Step $1^{\prime}$, proceed to Step $1^{2}$ using the machine layout obtained in Step $2^{1}$ as input.

Step 1': The machine layout obtained from Step $2^{\prime}$ (Table 4.7) is used as input data for the second part assignment model. The resulting objective function value is $\$ 88,882$ and the part assignment is given in Table 4.8. Since the part assignment is not the same as the input in Step $2^{1}$, proceed to Step $2^{2}$ using the part assignment obtained in Step $1^{2}$ as input.

Step $2^{2}$ : Using the part assignment obtained from Step $1^{2}$ (Table 4.8) as input data for the machine location model, the new machine layout (Table 4.9) is obtained. The resulting objective function value is $\$ 88,525$. Since the machine location is not the same as the input in Step $1^{2}$, proceed to Step $1^{3}$ using the machine layout obtained in Step $2^{2}$ as input.

Step 1 ${ }^{3}$ : The machine layout obtained from Step $2^{2}$ (Table 4.9) is used as input data for the second part assignment model. The resulting objective function value is $\$ 86,280$ and the part assignment is given in Table 4.10.

Continuing the iterative process results in the repetition of the solutions obtained in Steps 
$2^{2}$ and $1^{3}$. Therefore, Steps $2^{2}$ and $1^{3}$ converged to the machine layout (Table 4.9) and part assignment (Table 4.10). Comparing the results to the one obtained from Example 3.1 , it is found that the objective value is less than $0.01 \%$ worse in the iterative procedure case. The results from Examples 4.1 and 4.2 are summarized in Table 4.12.

\subsection{Computational Experience}

The results obtained from both the crisp and fuzzy linear models of Chapter 3 along with the fuzzy iterative procedure when solving Examples 4.1 and 4.2 are also included in Table 4.12. As evidenced in Examples 4.1 and 4.2, the iterative procedure may converge to the local optima. Also, the results from the iterative procedure depend upon the initial machine layout provided. Therefore, it is recommended that the iterative procedure be tried a few times with different initial machine layouts.

Three additional examples are also included in Table 4.12. Specifically, Examples 4.3, 4.4 and 4.5 are the same as Example 4.1 with the following exceptions:

- In Example 4.3, the machine capacity was doubled from 124,800 to 249,600 minutes.

- In Example 4.4, two additional parts 9 and 10 with a demand of 100 and 40, respectively, were added (refer to Table 4.11 for processing time/costs). 
- In Example 4.5, machines 6 and 8 are no longer fixed in positions 1 and 8 , respectively, and are permitted to relocate.

As evidenced when examining Table 4.12 differences are evident in the computational time required for solving the different models. Another observation that can be made is that the results between the linear models and the iterative procedure are very close or exactly the same.

The program used for solving all of the mathematical models presented in this thesis is HyperLindo. A summary for the sizes of each model (in terms of the number of continuous and integer variables and the number of constraints) can be found in Table 4.13.

\subsection{Summary}

The mathematical models presented in Chapter 3 are computationally time consuming. Therefore, in order to reduce the computation time, alternative crisp and fuzzy non-linear mathematical models are developed. These non-linear models can be decomposed into two sub-models, namely part allocation and machine location models. An iterative procedure uses the two sub-models to converge to a solution. The linear models of Chapter 3 required approximately 5 minutes 7 seconds of computation time to solve it 
optimally, while both the part assignment and machine location models took approximately 10 seconds of computation time for each model (all mathematical models were solved using the Hyperlindo software package on a PC $486 / 33 \mathrm{MHz}$ ). Since this solution strategy is a heuristic, the solution does not always yield the global optimal but was found to consistently be near optimal. The major advantage the iterative procedure provides is in a vast reduction of computation time. 
Table 4.1: Initial Machine Layout (Example 4.1)

\begin{tabular}{|c|c|c|c|c|c|c|c|c|}
\hline & \multicolumn{8}{|c|}{ Machine } \\
\cline { 2 - 9 } & 1 & 2 & 3 & 4 & 5 & 6 & 7 & 8 \\
\hline In Location & 7 & 2 & 5 & 4 & 6 & 1 & 3 & 8 \\
\hline
\end{tabular}

Table 4.2: Parts Assignment - Step 1' (Example 4.1)

\begin{tabular}{|c|c|c|c|c|c|c|c|c|c|}
\hline \multirow{2}{*}{ Part } & \multirow{2}{*}{ Operation } & \multicolumn{8}{|c|}{ Machine } \\
\hline & & 1 & 2 & 3 & 4 & 5 & 6 & 7 & 8 \\
\hline \multirow{3}{*}{1} & 1 & 100 & & & & & & & \\
\hline & 2 & 100 & & & & & & & \\
\hline & 3 & & & & & & & & 100 \\
\hline \multirow{3}{*}{2} & 1 & & & & & 700 & & & \\
\hline & 2 & & & & 700 & & & & \\
\hline & 3 & & 700 & & & & & & \\
\hline \multirow{2}{*}{3} & 1 & & & & & & & 800 & \\
\hline & 2 & & & & & & 800 & & \\
\hline \multirow{2}{*}{4} & 1 & & & 600 & & & & & \\
\hline & 2 & & & & & 600 & & & \\
\hline \multirow{3}{*}{5} & 1 & 35 & 20 & & & & & & \\
\hline & 2 & & & & 55 & & & & \\
\hline & 3 & & & & & & & 55 & \\
\hline \multirow{2}{*}{6} & 1 & & & & & & 900 & & \\
\hline & 2 & & 900 & & & & & & \\
\hline \multirow{2}{*}{7} & I & & & 700 & & & & & \\
\hline & 2 & 700 & & & & & & & \\
\hline \multirow{3}{*}{8} & 1 & & & & & & & 900 & \\
\hline & 2 & & & & 883 & & 17 & & \\
\hline & 3 & & & & 883 & 17 & & & \\
\hline
\end{tabular}


Table 4.3: Machine Layout - Step 2' (Example 4.1)

\begin{tabular}{||c|c|c|c|c|c|c|c|c||}
\hline \multirow{2}{*}{} & \multicolumn{10}{|c|}{ Machine } \\
\cline { 2 - 9 } & 1 & 2 & 3 & 4 & 5 & 6 & 7 & 8 \\
\hline In Location & 6 & 2 & 5 & 4 & 7 & 1 & 3 & 8 \\
\hline
\end{tabular}

Table 4.4: Parts Assignment - Step $1^{2}$ (Example 4.1)

\begin{tabular}{|c|c|c|c|c|c|c|c|c|c|}
\hline \multirow{2}{*}{ Part } & \multirow{2}{*}{ Operation } & \multicolumn{8}{|c|}{ Machine } \\
\hline & & 1 & 2 & 3 & 4 & 5 & 6 & 7 & 8 \\
\hline \multirow{3}{*}{ I } & 1 & 100 & & & & & & & \\
\hline & 2 & 100 & & & & & & & \\
\hline & 3 & & & & & & & & 100 \\
\hline \multirow{3}{*}{2} & 1 & & & & & 700 & & & \\
\hline & 2 & & & & 700 & & & & \\
\hline & 3 & & 648 & 52 & & & & & \\
\hline \multirow{2}{*}{3} & 1 & & & & & & & 800 & \\
\hline & 2 & & & & & & 800 & & \\
\hline \multirow{2}{*}{4} & 1 & & & 600 & & & & & \\
\hline & 2 & & & & & 600 & & & \\
\hline \multirow{3}{*}{5} & 1 & & 55 & & & & & & \\
\hline & 2 & & & & 55 & & & & \\
\hline & 3 & & & & & & & 55 & \\
\hline \multirow{2}{*}{6} & 1 & & & & & & 900 & & \\
\hline & 2 & & 900 & & & & & & \\
\hline \multirow{2}{*}{7} & 1 & & & 700 & & & & & \\
\hline & 2 & 700 & & & & & & & \\
\hline \multirow{3}{*}{8} & 1 & & & & & & & 900 & \\
\hline & 2 & & & & 900 & & & & \\
\hline & 3 & & & & 880 & 20 & & & \\
\hline
\end{tabular}


Table 4.5: Initial Machine Layout (Example 4.2)

\begin{tabular}{||c|c|c|c|c|c|c|c|c|}
\hline & \multicolumn{10}{|c|}{ Machine } \\
\cline { 2 - 9 } & 1 & 2 & 3 & 4 & 5 & 6 & 7 & 8 \\
\hline In Location & 7 & 2 & 5 & 3 & 4 & 1 & 6 & 8 \\
\hline
\end{tabular}

Table 4.6: Parts Assignment - Step 1' (Example 4.2)

\begin{tabular}{|c|c|c|c|c|c|c|c|c|c|}
\hline \multirow{2}{*}{ Part } & \multirow{2}{*}{ Operation } & \multicolumn{8}{|c|}{ Machine } \\
\hline & & 1 & 2 & 3 & 4 & 5 & 6 & 7. & 8 \\
\hline \multirow{3}{*}{1} & 1 & 100 & & & & & & & \\
\hline & 2 & 100 & & & & & & & \\
\hline & 3 & & & & & & & & 100 \\
\hline \multirow{3}{*}{2} & 1 & & & & & 700 & & & \\
\hline & 2 & & & & 700 & & & & \\
\hline & 3 & & 700 & & & & & & \\
\hline \multirow{2}{*}{3} & 1 & & & & & & & & 800 \\
\hline & 2 & 800 & & & & & & & \\
\hline \multirow{2}{*}{4} & 1 & & & 600 & & & & & \\
\hline & 2 & & & & & 600 & & & \\
\hline \multirow{3}{*}{5} & 1 & 35 & 20 & & & & & & \\
\hline & 2 & & & & 55 & & & & \\
\hline & 3 & & & & & & & & 55 \\
\hline \multirow{2}{*}{6} & 1 & & & & & & 900 & & \\
\hline & 2 & & 900 & & & & & & \\
\hline \multirow{2}{*}{7} & 1 & & & 700 & & & & & \\
\hline & 2 & 700 & & & & & & & \\
\hline \multirow{3}{*}{8} & 1 & & & & & & & 76 & 824 \\
\hline & 2 & & & & 900 & & & & \\
\hline & 3 & & & & 414 & 486 & & & \\
\hline
\end{tabular}


Table 4.7: Machine Layout - Step $2^{\prime}$ (Example 4.2)

\begin{tabular}{|c|c|c|c|c|c|c|c|c|}
\hline & \multicolumn{8}{|c|}{ Machine } \\
\cline { 2 - 9 } & 1 & 2 & 3 & 4 & 5 & 6 & 7 & 8 \\
\hline In Location & 6 & 2 & 5 & 7 & 4 & 1 & 3 & 8 \\
\hline
\end{tabular}

Table 4.8: Parts Assignment - Step $1^{2}$ (Example 4.2)

\begin{tabular}{|c|c|c|c|c|c|c|c|c|c|}
\hline \multirow{2}{*}{ Part } & \multirow{2}{*}{ Operation } & \multicolumn{8}{|c|}{ Machine } \\
\hline & & 1 & 2 & 3 & 4 & 5 & 6 & 7 & 8 \\
\hline \multirow{3}{*}{1} & 1 & & 100 & & & & & & \\
\hline & 2 & & & & & & 100 & & \\
\hline & 3 & & & & & & & 100 & \\
\hline \multirow{3}{*}{2} & 1 & & & & & 700 & & & \\
\hline & 2 & & & & 700 & & & & \\
\hline & 3 & & & 700 & & & & & \\
\hline \multirow{2}{*}{3} & 1 & & & & & & & 800 & \\
\hline & 2 & & & & & & 800 & & \\
\hline \multirow{2}{*}{4} & 1 & & & 600 & & & & & \\
\hline & 2 & & & & & 600 & & & \\
\hline \multirow{3}{*}{5} & 1 & 55 & & & & & & & \\
\hline & 2 & & & & 55 & & & & \\
\hline & 3 & & & & & & & & 55 \\
\hline \multirow{2}{*}{6} & 1 & & & & & & 900 & & \\
\hline & 2 & & 900 & & & & & & \\
\hline \multirow{2}{*}{7} & 1 & & & 700 & & & & & \\
\hline & 2 & 700 & & & & & & & \\
\hline \multirow{3}{*}{8} & 1 & & & & & & & 17 & 883 \\
\hline & 2 & & & & 883 & & 17 & & \\
\hline & 3 & & & & 883 & 17 & & & \\
\hline
\end{tabular}


Table 4.9: Machine Layout - Step $2^{2}$ (Example 4.2)

\begin{tabular}{||c|c|c|c|c|c|c|c|c||}
\hline \hline & \multicolumn{10}{|c||}{ Machine } \\
\cline { 2 - 9 } & 1 & 2 & 3 & 4 & 5 & 6 & 7 & 8 \\
\hline In Location & 4 & 2 & 5 & 7 & 6 & 1 & 3 & 8 \\
\hline
\end{tabular}

Table 4.10: Parts Assignment - Step $1^{3}$ (Example 4.2)

\begin{tabular}{|c|c|c|c|c|c|c|c|c|c|}
\hline \multirow{2}{*}{ Part } & \multirow{2}{*}{ Operation } & \multicolumn{8}{|c|}{ Machine } \\
\hline & & 1 & 2 & 3 & 4 & 5 & 6 & 7 & 8 \\
\hline \multirow{3}{*}{1} & 1 & & 100 & & & & & & \\
\hline & 2 & & & & & & 100 & & \\
\hline & 3 & & & & & & & 100 & \\
\hline \multirow{3}{*}{2} & 1 & & & & & 700 & & & \\
\hline & 2 & & & & 700 & & & & \\
\hline & 3 & & & 700 & & & & & \\
\hline \multirow{2}{*}{3} & I & & & & & & & 800 & \\
\hline & 2 & & & & & & 800 & & \\
\hline \multirow{2}{*}{4} & 1 & & & 600 & & & & & \\
\hline & 2 & & & & & 600 & & & \\
\hline \multirow{3}{*}{5} & 1 & 55 & & & & & & & \\
\hline & 2 & & & & 55 & & & & \\
\hline & 3 & & & & & & & & 55 \\
\hline \multirow{2}{*}{6} & 1 & & & & & & 900 & & \\
\hline & 2 & 900 & & & & & & & \\
\hline \multirow{2}{*}{7} & 1 & & & 700 & & & & & \\
\hline & 2 & & 700 & & & & & & \\
\hline \multirow{3}{*}{8} & 1 & & & & & & & & 900 \\
\hline & 2 & & & & 900 & & & & \\
\hline & 3 & & & & 880 & 20 & & & \\
\hline
\end{tabular}


Table 4.11: Cost/Time(min) per Part Operation for each Machine

\begin{tabular}{||c|c|c|c|c|c|c|c|c|c||}
\hline \hline \multirow{3}{*}{ Part } & \multirow{2}{*}{ Operation } & \multicolumn{7}{|c||}{ Machine } \\
\cline { 2 - 12 } & & 1 & 2 & 3 & 4 & 5 & 6 & 7 & 8 \\
\hline \multirow{3}{*}{9} & 1 & $2 / 20$ & $2 / 20$ & & & & & & \\
\cline { 2 - 12 } & 2 & & & & $3.5 / 35$ & & & & \\
\hline \multirow{3}{*}{10} & 1 & & & & $1.5 / 15$ & & $1 / 10$ & & \\
\cline { 2 - 12 } & 2 & & & & & & $1 / 10$ & & \\
\cline { 2 - 11 } & 3 & & & & & & & $2 / 20$ & $2 / 20$ \\
\hline
\end{tabular}

Table 4.12: Summary of Results

\begin{tabular}{|c|c|c|c|c|c|c|c|c|c|}
\hline \multirow{3}{*}{$\begin{array}{c}\mathrm{E} \\
\mathrm{x} \\
\mathrm{a} \\
\mathrm{m} \\
\mathrm{p} \\
\mathrm{l} \\
\mathrm{e}\end{array}$} & \multicolumn{4}{|c|}{ Linear Models (Chapter 3) } & \multicolumn{5}{|c|}{ Iterative Procedure (Chapter 4) } \\
\hline & \multicolumn{2}{|c|}{ Crisp } & \multicolumn{2}{|c|}{ Fuzzy } & \multicolumn{2}{|c|}{ Crisp } & \multicolumn{2}{|c|}{ Fuzzy } & \multirow[b]{2}{*}{$\begin{array}{l}\text { Number } \\
\text { of } \\
\text { Iterations }\end{array}$} \\
\hline & $\begin{array}{l}\text { Obj. } \\
\text { Funct. } \\
\text { (\$) }\end{array}$ & $\begin{array}{l}\text { Comp. } \\
\text { Time } \\
\text { (h:m:s) }\end{array}$ & $\begin{array}{l}\text { Obj. } \\
\text { Funct. } \\
(\$)\end{array}$ & $\begin{array}{l}\text { Comp. } \\
\text { Time } \\
\text { (h:m:s) }\end{array}$ & $\begin{array}{l}\text { Obj. } \\
\text { Funct. } \\
(\$)\end{array}$ & $\begin{array}{l}\text { Comp. } \\
\text { Time } \\
\text { (h:m:s) }\end{array}$ & $\begin{array}{l}\text { Obj. } \\
\text { Funct. } \\
(\$)\end{array}$ & $\begin{array}{l}\text { Comp. } \\
\text { Time* } \\
\text { (h:m:s) }\end{array}$ & \\
\hline 4.1 & 85,855 & $0: 05: 07$ & 83,468 & $0: 05: 42$ & 85,855 & $0: 00: 10$ & 83,468 & $0: 00: 30$ & 2 \\
\hline 4.2 & 85,855 & $0: 05: 07$ & 83,468 & $0: 05: 42$ & 86,280 & $0: 00: 14$ & 83,949 & $0: 00: 40$ & 3 \\
\hline 4.3 & 85,265 & $0: 04: 35$ & 83,133 & $0: 03: 45$ & 85,265 & $0: 00: 10$ & 83,133 & $0: 00: 30$ & 2 \\
\hline 4.4 & 87,341 & $0: 08: 15$ & 85,524 & $0: 11: 40$ & 87,341 & $0: 00: 25$ & 85,524 & $0: 00: 30$ & 2 \\
\hline 4.5 & 85,855 & $0: 55: 00$ & 83,468 & $1: 48: 00$ & 85,855 & $0: 15: 30$ & 83,468 & $0: 30: 00$ & 2 \\
\hline
\end{tabular}

Total time for all iterations. 
Table 4.13: Summary of Model Size

\begin{tabular}{|c|c|c|c|c|c|c|c|}
\hline & \multirow[b]{3}{*}{ Example } & \multirow{2}{*}{\multicolumn{2}{|c|}{$\begin{array}{l}\text { Linear Models } \\
\text { (Chapter 3) }\end{array}$}} & \multicolumn{4}{|c|}{ Iterative Procedure (Chapter 4) } \\
\hline & & & & \multicolumn{2}{|c|}{ Crisp } & \multicolumn{2}{|c|}{ Fuzzy } \\
\hline & & Crisp & Fuzzy & $\begin{array}{c}\text { Machine } \\
\text { Location } \\
\text { Model }\end{array}$ & $\begin{array}{c}\text { Part } \\
\text { Allocation } \\
\text { Model }\end{array}$ & $\begin{array}{c}\text { Machine } \\
\text { Location } \\
\text { Model }\end{array}$ & $\begin{array}{c}\text { Part } \\
\text { Allocation } \\
\text { Model }\end{array}$ \\
\hline 4.1 & $\begin{array}{l}\text { Continuous } \\
\text { Integer } \\
\text { Constraints }\end{array}$ & $\begin{array}{c}354 \\
20 \\
139\end{array}$ & $\begin{array}{c}355 \\
20 \\
148\end{array}$ & $\begin{array}{c}0 \\
166 \\
169\end{array}$ & $\begin{array}{c}72 \\
0 \\
54\end{array}$ & $\begin{array}{c}0 \\
166 \\
169\end{array}$ & $\begin{array}{c}73 \\
0 \\
55\end{array}$ \\
\hline 4.2 & $\begin{array}{l}\text { Continuous } \\
\text { Integer } \\
\text { Constraints }\end{array}$ & $\begin{array}{c}354 \\
20 \\
139\end{array}$ & $\begin{array}{l}355 \\
20 \\
148\end{array}$ & $\begin{array}{c}0 \\
166 \\
169\end{array}$ & $\begin{array}{c}72 \\
0 \\
54\end{array}$ & $\begin{array}{c}0 \\
166 \\
169\end{array}$ & $\begin{array}{c}73 \\
0 \\
55\end{array}$ \\
\hline 4.3 & $\begin{array}{l}\text { Continuous } \\
\text { Integer } \\
\text { Constraints }\end{array}$ & $\begin{array}{l}354 \\
20 \\
139\end{array}$ & $\begin{array}{c}355 \\
20 \\
148\end{array}$ & $\begin{array}{c}0 \\
166 \\
169\end{array}$ & $\begin{array}{c}72 \\
0 \\
54\end{array}$ & $\begin{array}{c}0 \\
166 \\
169\end{array}$ & $\begin{array}{c}73 \\
0 \\
55\end{array}$ \\
\hline 4.4 & $\begin{array}{l}\text { Continuous } \\
\text { Integer } \\
\text { Constraints }\end{array}$ & $\begin{array}{c}403 \\
20 \\
159\end{array}$ & $\begin{array}{c}404 \\
20 \\
168\end{array}$ & $\begin{array}{c}0 \\
177 \\
169\end{array}$ & $\begin{array}{c}85 \\
0 \\
64\end{array}$ & $\begin{array}{c}0 \\
177 \\
169\end{array}$ & $\begin{array}{c}86 \\
0 \\
65\end{array}$ \\
\hline 4.5 & $\begin{array}{l}\text { Continuous } \\
\text { Integer } \\
\text { Constraints }\end{array}$ & $\begin{array}{l}725 \\
38 \\
166\end{array}$ & $\begin{array}{c}726 \\
38 \\
175\end{array}$ & $\begin{array}{c}0 \\
622 \\
693\end{array}$ & $\begin{array}{c}72 \\
0 \\
54\end{array}$ & $\begin{array}{c}0 \\
622 \\
693\end{array}$ & $\begin{array}{c}73 \\
0 \\
54\end{array}$ \\
\hline
\end{tabular}




\subsection{CONCLUSIONS}

This chapter is organized as follows. The contributions of the research is detailed in Section 5.1. Section 5.2 identifies areas that can be explored in future research.

\subsection{Contributions of the Research}

In Chapter 3, crisp and fuzzy mathematical models that determine optimal cell formation were presented. The models trade-off the cost of intercell and intracell movement with processing costs. When there is known uncertainty in the input data, a fuzzy mathematical model can be used to determine the optimal cell formation. In the cases analyzed, the fuzzy data occurred in the machine capacity and part demand. When the fuzziness is incorporated into the models, the results have been shown to differ from that of the crisp mathematical models. Therefore, as evidenced in the examples provided, the uncertainty of the data is an important consideration that must be taken into account if practical solutions are to be obtained.

The mathematical models presented in Chapter 3 are computationally time consuming. To reduce computation time, alternative non-linear formulations for the crisp and fuzzy mathematical models (presented in Chapter 3) were developed. These non-linear models are decomposed into two linear sub-models; namely, the part allocation and the machine 
location models. The iterative procedure utilizes these sub-models by using the solution obtained from one model as input for the other model. This iterative procedure continues until the sub-models converge to a solution. A number of examples were provided to compare the computation time required by the iterative procedure versus the linear models of Chapter 3.

\subsection{Scope for Future Research}

There are a number of areas that can be explored for future research.

These areas include:

- Include fuzzy coefficients for the processing time and processing costs for a parts individual operation. This is very realistic especially where the processing is manually intensive.

- Include fuzziness in material handling distances and costs.

- Solve the linear fuzzy mathematical model using a different derivation for the membership functions (such as a trapezoidal or triangular form) along with an objective of minimizing average cost per part to see what effect it has on part production \assignment.

- Other alternative solution strategies can be utilized and compared for their efficiency, results and ease of use. 


\section{REFERENCES}

1. Adil, G. K., 1994, Design of the cell system of production, Unpublished Doctoral Dissertation, University of Manitoba, Winnipeg, Manitoba, Canada.

2. Ahmed, M. U., Ahmed N. U. and Nandkeolyar, U., 1991, A volume and material handling cost based heuristic for designing cellular manufacturing cells, Journal of Operations Management, 10 (4), 488-511.

3. Askin, R. G. and Mitwasi, M. G., 1992, Integrating facility layout with process selection and capacity planning, European Journal of Operational Research, 57, 162-173.

4. Atmani, A., Lashkari, R. S. and Caron, R. J., 1995, A mathematical programming approach to joint cell formation and operation allocation in cellular manufacturing, International Journal Of Production Research, 33 (1), 1-15.

5. Choobineh, F., 1988, A framework for the design of cellular manufacturing systems, International Journal Of Production Research, 26 (7), 1161-1172.

6. Chu, C. H. and Hayya, J. C., 1991, A fuzzy clustering approach to manufacturing cell formation, International Journal Of Production Research, 29 (7), 1475-1487.

7. Chu, C. H. and Tsai, C. C., 1993, Manufacturing cell formation in a fuzzy environment, Proceedings Of The National Decision Sciences Conference, 3, 1432 1434.

8. Dahel, N. E., 1995, Design of cellular manufacturing systems in tandem configuration, International Journal Of Production Research, 33 (8), 2079-2095. 
9. Del Valle, A. G., Balarezo, S. and Tejero, J., 1994, A heuristic workload-based model to form cells by minimizing intercellular movements, International Journal of Production Research, 32 (10), 2275-2285.

10. Grznar, J., Mehrez, A. and Offodile, O. F., 1994, Formulation of the machine cell grouping problem with capacity and material movement constraints, Joumal of Manufacturing Systems, 13 (4), 241-250.

11. Gunasingh, K. R. and Lashkari, R. S., 1989, Machine grouping problem in cellular manufacturing systems-an integer programming approach, International Journal of Production Research, 27 (9), 1465-1473.

12. Gupta, T. and Seifoddini, H., 1990, Production data based similarity coefficient for machine-component grouping decisions in the design of a cellular manufacturing system, International Journal Of Production Research, 28 (7), 1247-1269.

13. Heragu, S. S., 1994, Group technology and cellular manufacturing, IEEE Transactions On Systems, Man, And Cybernetics, 24 (2), 203-215.

14. Irani, S. A., Cavalier, T. M. and Cohen, P. H., 1993, Virtual manufacturing cells: exploiting layout design and intercell flows for the machine sharing problem, International Journal Of Production Research, 31 (4), 791-810.

15. Kang, S. -L. and Wemmerlov, U., 1993, A work load-oriented heuristic methodology for manufacturing cell formation allowing reallocation of operations, European Journal Of Operational Research, 69, 292-311. 
16. Kasilingam, R. G. and Sankaran, S., 1991, Capacity selection by mathematical programming in cellular manufacturing systems, Production Planning \& Control, $2(4), 353-358$

17. Kusiak, A., 1987, The generalized group technology concept, International Journal Of Production Research, 25 (4), 561-569.

18. Logendran, R. and Ramakrishna, P., 1995, Manufacturing cell formation in the presence of lot splitting and multiple units of the same machine, International Journal Of Production Research, 33 (3), 375-693.

19. Logendran, R., 1991, Impact of sequence of operations and layout of cells in cellular manufacturing, International Journal Of Production Research, 29 (2), 375390.

20. Logendran, R., 1990, A workload based model for minimizing total intercell and intracell moves in cellular manufacturing, International Journal Of Production Research, 28 (5), 913-925.

21. Murthy, Ch. V. R and Srinivasan, G., 1995, Fractional cell formation in group technology, International Journal Of Production Research, 33 (5), 1323-1337.

22. Narayanaswamy, P., 1995, Machine grouping and part family formation problems in cellular manufacturing, Unpublished Master of Science Thesis, University of Manitoba, Winnipeg, Manitoba, Canada.

23. Rajamani, D. and Szwarc, D., 1994, A mathematical model for multiple machine replacement with material handling and relocation considerations, Engineering Optimization, 22, 213-229. 
24. Rajamani, D., Singh, N. and Aneja, Y. P., 1992, Selection of parts and machines for cellularization: a mathematical programming approach, European Journal of Operational Research, 62, 47-54.

25. Rajamani, D., Singh, N. and Aneja, Y. P., 1992, A model for cell formation in manufacturing systems with sequence dependence, International Journal of Production Research, 30 (6), 1227-1235.

26. Rajamani, D., Singh, N. and Aneja, Y. P., 1990, Integrated design of cellular manufacturing systems in the presence of alternative process plans, International Journal Of Production Research, 28 (8), 1541-1554.

27. Sankaran, S. and Kasilingam, R. G., 1993, On cell size and machine requirements in planning group technology systems, European Journal of Operational Research, 69, 373-383.

28. Shafer, S. M. and Meredith, J. R., 1990, A comparison of selected manufacturing cell formation techniques, International Journal of Production Research, 28 (4), $661-673$.

29. Song, S. and Hitomi, K., 1992, GT cell formation for minimizing the intercell parts flow, International Journal of Production Research, 30 (12), 2737-2753.

30. Srinivasan, G., Narendran, T. T. and Mahadevan, B., 1989, An assignment model for the part-families problem in group technology, International Journal of Production Research, 20 (1), 145-152.

31. Tanaka, H. and Asai, K., 1984, Fuzzy linear programming problems with fuzzy numbers, Fuzzy Sets And Systems, 13, 1-10. 
32. Wemmerlov, U. and Hyer, N. L., 1986, Procedures for the part family/machine group identification problem in cellular manufacturing, Journal Of Operations Management, 6 (2), 125-147.

33. Xu, H. and Wang, H. -P., 1989, Part family formation for GT applications based on fuzzy mathematics, International Journal of Production Research, 27 (9), 1637 1651.

34. Zadeh, L. A., 1965, Fuzzy Sets, Information and Control, 8, 338-353.

35. Zhang, C. and Wang, H. -P., 1992, Concurrent formation of part families and machine cells based on the fuzzy set theory, Journal Of Manuficturing Systems, 11 (1), 61-67.

36. Zimmerman, H. J., 1991, Fuzzy set theory and its application, Kluwer Academic Publishers, Boston\DordrechtLondon, Second, Revised Edition, 248-261. 


\section{VITA AUCTORIS}

1970 Born in Winnipeg, Manitoba on the $30^{\text {th }}$ of September.

1988 Obtained Grade XII diploma from Silver Heights Collegiate, Winnipeg, Manitoba.

1992 Graduated from the University of Manitoba, Winnipeg, Manitoba with a Bachelor of Science degree in Industrial Engineering.

1996 Currently a candidate for the award of the degree of Master of Science in Industrial Engineering from the University of Manitoba, Winnipeg, Manitoba. 